\title{
Regional Blocks and Imperial Legacies: Mapping the Global Offshore FDI Network
}

\begin{abstract}
While FDI is generally assumed to represent long-term investments within the "real" economy, approximately 30-50\% of global FDI is accounted for by networks of offshore shell companies created by corporations and individuals for tax and other purposes. To date, there has been limited systematic research on the global structure of these networks. Here we address this gap by employing Principal Component Analysis (PCA) to decompose the global bilateral FDI anomaly matrix into its primary constituent sub-networks. We find that the global offshore FDI network is highly globalized, with a centralized "Network Core" of jurisdictions in Northwest Europe and the Caribbean exercising a largely homogenous worldwide influence. To the extent that the network is internally differentiated, this appears to primarily reflect a historical layering of social and political relationships. We identify four primary offshore FDI sub-networks, bearing the imprint of four key processes and events: European, particularly UK colonialism, the post-WWII hegemonic alliance between the US and Western Europe, the fall of Soviet communism, and the rise of Chinese capitalism. We also find evidence of qualitative, but not quantitative variation in offshore FDI based on national rule of law and communist history.
\end{abstract}

Key Words: Offshore financial centers, FDI, Principal component analysis, Global financial network, Investment vehicles, Shell companies, BRICs, British Empire

\section{Introduction}

In recent years, commentators on research in economic geography have expressed dissatisfaction with traditional approaches to the study of finance (Aoyama et al. 2011; Lee et al. 
2009). This has, by and large, been limited to a financial geography largely separated from the study of productive activity within the broader sub-discipline. While each of these lines of research has been fruitful in and of itself, their dearth of integration has hindered the full problematization of a bundle of changes in the global economy referred to as "financialization." More than simply a growing weight of finance on top of the "real" economy, these have both entailed and driven fundamental shifts in the organization of production (Baud and Durand 2012; Coe et al. 2014; Milberg 2008; Palpacuer 2008). Indeed, the intersection of financialization and the "knowledge economy" have called into question the definition of production, with corporate strategy increasingly structured around the extraction of value from "intangible" intellectual property as a financial asset (Lazonick and Tulum 2011; Seabrooke and Wigan 2014).

From a geographic standpoint, there is a growing awareness that the integration of research on finance and the "real" economy must take into account not only the role of "world cities" as financial command centers in global capitalism, but also the role of Offshore Jurisdictions (OJs) in defining its institutional landscape (Coe et al. 2014; Seabrooke and Wigan 2014). Underscoring this is the ongoing transformation of the organization and function of foreign direct investment (FDI) within the global economy. While traditionally interpreted as a reflection of the real operations of multinational firms, FDI has become increasingly dominated by networks of abstract financial accounting entities spanning onshore and offshore jurisdictions. The extent of this can be seen in Bureau of Economic Analysis data on US FDI (BEA 2013), with more than half of the FDI stock of US non-financial firms, or 1.9 out of 3.6 trillion dollars, attributed to overseas holding companies rather than functional subsidiaries as of 2012. More than half of the assets of these - nearly a third of the total FDI stock of US firms - were in turn reported in three leading OJs, the Netherlands, Luxembourg, and Bermuda (BEA 2013). Such 
behavior is not limited to US firms; all told, at least 30\%, and likely closer to $50 \%$ of world FDI can be described as "offshore" FDI lacking a direct attachment to productive activity in the economy where it is reported (Palan et al. 2010; authors' analysis ${ }^{1}$ ).

The use of offshore subsidiaries for tax avoidance by multinational corporations is the subject of intense media and political controversy, particularly in the UK (Barford and Holt 2013). Meanwhile, the role of offshore jurisdictions as domiciles for Special Purpose Vehicles (SPVs) engaged in "shadow banking" has led some to implicate them in the 2008 financial crisis (Wójcik 2013a; Shaxson 2011), while offshore shell companies have been argued to play a central role in siphoning capital out of and enabling corruption in developing countries (Baker 2005; Oxfam 2000). Notwithstanding this attention, however, our understanding of offshore FDI is fragmentary in nature, with only a limited empirical basis to adjudicate between conflicting perspectives. Indeed, a superficial consensus regarding the scope of the offshore "problem" belies a lack of scholarly agreement on such fundamental issues as whether offshore activity is attracted to or repelled by financial regulation, or the extent to which its organization should be understood with reference to a timescale of centuries as opposed to an individual business day (Baker 2005; Palan et al. 2010: Roberts 1994: Sharman 2012; Shaxson 2011; Vlcek 2013).

This study aims to contribute to the resolution and refinement of conceptual debates surrounding offshore finance, by producing and analyzing the first comprehensive map of global offshore FDI network organization. By applying Principal Component Analysis (PCA) to a new IMF bilateral FDI database encompassing an unprecedentedly large matrix of jurisdictions, we demonstrate that the global offshore FDI network can be described in terms of only a handful of primary underlying sub-networks linking groups of offshore and real economies, which are in

\footnotetext{
' $50 \%$ rough estimate based on our analysis of the IMF CDIS, including Dutch FDI as "offshore" (see figure 1).
} 
turn nested within a dominant global network structure. The structure of these sheds light on the processes shaping the integration of OJs into the global economy. We find the first systematic evidence that an economy's engagement with OJs is shaped by its institutional characteristics, with reliance on trust and face-to-face contact apparently conditioned by the interaction between rule of law and communist history. Our results also cast doubt on the idea that the geography of the offshore world is highly footloose and technology-driven, suggesting that it has rather been built up through a historical layering of political and social relationships. A small number of historical processes and events appear to have been of decisive importance: the establishment of global empires by the UK, and to a lesser extent other European countries, the shift in economic and political hegemony from the UK to the US and its allies, the collapse of Soviet communism, the rise of Chinese capitalism, and financial globalization as an overarching process.

The remainder of the paper is organized into six sections. Section 2 first examines the definition of offshore finance, and its ontologically situation within economic geographic theory, before examining gaps in our understanding of offshore network architecture, focusing on conceptual controversies regarding its institutional drivers and historical and relational "stickiness." In the following section, we introduce the IMF coordinated direct investment survey (CDIS) dataset, and the use of principal component analysis (PCA) to deconstruct the global FDI anomaly matrix into its constituent sub-networks. Each of these networks is examined in turn in section 4 , which closes with an analysis of the core structures linking them together. Section 5 discusses the implications of these structures for our understanding of the evolution and operation of the offshore network, supplementing the PCA results themselves with regression tests of hypotheses suggested by these results. We conclude by discussing directions for extension of the research presented here, and its potential relevance to policy. 


\section{Offshore Jurisdictions in the Global Financial Network}

The offshore world is sometimes portrayed as existing in small island jurisdictions at the periphery of the global political and economic order. What defines offshore finance, however, is less the jurisdiction within which transactions are booked or conducted, than their conduct in a networked transnational legal space produced by the lack of a clear legal basis for multinational activity. As each state defines which entities and transactions are "national" or "foreign," these can often be structured to fall, for various purposes, outside of the jurisdiction claimed by any state (Picciotto 1999). An OJ, in this sense, can be considered to be one which organizes its laws, in relation to those of other jurisdictions, to facilitate these strategies of escape in matters of tax, regulatory oversight, transparency, or all of the above. While this cannot always be done legally from the standpoint of other governments, this can be sidestepped through financial secrecy, which as such enables the mechanism of jurisdictional arbitrage (Palan et. al. 2010).

These processes present a conceptual challenge to economic geography, which has generally sought to look past monetary and legal abstractions to the production systems and human relationships through which economic activity is constituted. As Coates and Rafferty (2007, p. 38) note, "by attaching labels such as hot money, tax havens or speculative capital to these developments, there has been a tendency to shut down analysis before it even begins." Beyond the study of production, this orientation has to some extent structured the geography of finance, which has problematized relationships and information-flows between firms and people (Clark and O'Connor 1997; Thrift 1994) more than the constitution of finance itself (Leyshon and Thrift 1997). This is particularly evident in research on financial centers, which has in recent years been strongly influenced by a World City Network (WCN) framework emphasizing 
the human and corporate infrastructure of global economic command-and-control (Beaverstock et al. 2000; Taylor 2000; Taylor et al. 2004).

Such an emphasis may be appropriate insofar as finance is analyzed as part of an economy oriented towards the production of goods and services. However, it provides an incomplete view of finance in the context of capitalism as a system of value extraction and wealth accumulation. Capital is a formal social construction, which cannot be understood without reference to the bundles of abstract legal titles and contracts through which it is constituted. With the growing importance of offshore legal constructs increasingly underscoring this point, recognition has begun to grow of the need to integrate this "fictitious" realm into economic geographic theory. Seabrooke and Wigan (2013) argue that research on the production and extraction of profits through global value chains must be complemented with an analysis of Global Wealth Chains (GWC), which use OJs to remove capital from fiscal, legal, and regulatory accountability. In a similar vein, Coe et al. (2014) propose a Global Financial Network (GFN) framework for integrating the role of OJs in structuring the organization of global capital, with WCN models of the geography of financial centers, and Global Production Network (GPN) models of the "real" economy. This focuses on three themes: financialization of GPN structure and operation, unbundling of legal jurisdiction from sites of actual activity, and outsourcing of high-level corporate functions and decisions to specialized financial, legal, accountancy, and consultancy Advanced Business Services (ABS) providers (Froud et al. 2000; Wójcik 2013a). These frameworks have different emphases, with GFN focusing on the "ABS Offshore Nexus" (Wójcik 2013a) linking functional (i.e. world city) and notional (i.e. offshore) financial activities, and the GWC perspective more directly problematizing capital accumulation, with an emphasis on the relationship between "intangible" knowledge-based and "fictitious" offshore 
capital. However, they share fundamental arguments and assumptions. Both are rooted in an understanding that the boundary between finance and the real economy has become ambiguous, as financial actors and principals have come to dominate command-and-control and accounting processes in most areas of economic activity. Moreover, both move beyond antagonistic models of state territoriality and the global economic "space of flows" (Taylor 2000), to problematize how state sovereignty has become constitutive of this space via offshore legal constructs.

While helping to close an ontological gap in economic geographic theory, this work outlines more of a research agenda than a concrete set of hypotheses regarding the geography of offshore finance. Indeed, our picture of this remains ambiguous with respect to fundamental conceptual questions, two of which stand out as particularly important. The first is the extent to which offshore financial ties are arms-length and footloose, as opposed to historically and relationally "sticky." In the context of onshore finance, technology-catalyzed time-space compression has clearly not undermined the importance of difficult-to-replicate trust-based relationships, institutional frameworks, and esoteric knowledge bases (Clark and O'Connor 1997; Thrift 1994). However, it is unclear to what extent this applies to offshore activities. Roberts (1994) stresses the immaterial, fictitious quality of offshore finance, and its potential to be controlled at a distance via electronic communications. According to this perspective, OJs serve as interchangeable platforms constantly at risk of being sidelined by regulatory developments in competitors, with the friction imposed by time zones on real-time communication the primary basis of geographic differentiation. However, another body of work emphasizes the importance of deeply rooted political and institutional structures (Palan et al. 2010; Shaxson 2011). Offshore activities, according to this view, are mediated through tight-knit networks linking specialized professionals to one another, regulators, and clients, which exhibit a 
high degree of geographic and historical inertia (Wainwright 2011). Looming largest within this inheritance is the legacy of European colonialism (Eden and Kudrle 2005; Palan et al. 2010; Shaxson 2011). Laws and institutions that facilitated the extraction of wealth by colonizers have sometimes proven to be useful for jurisdictional arbitrage, for example UK domiciliation and Dutch holding company laws (Palan et al. 2010). More importantly, colonialism established durable networks of political, economic, and cultural ties. In contrast to Roberts' (1994) argument that London's position as an offshore hub is vulnerable to competitive deregulation, this perspective sees London as the indispensable core of an offshore archipelago of current and former colonies, united in particular by the institution of common law (Palan et al. 2010). Some have referred to this as Britain's "second empire," albeit an empire dominated by the capital of former colonies, most importantly the United States (Palan et. al. 2010; Shaxson 2011; Wójcik 2013a).

The second set of key debates surrounding offshore finance relates to its role in shaping the "variegated capitalisms" produced through the transnational interaction of institutional and regulatory environments (Dixon 2011; Haberly 2014; Peck and Theodore 2007). Beyond an understanding that companies and individuals use OJs to reduce their taxes, sharply contrasting interpretations exist of their institutional role. Some emphasize the provision by OJs of strong institutional environments, which facilitate international investment, and offer more stringent property rights and general legal protections than many onshore jurisdictions (Desai et al. 2004; Dharmapala 2008; Hong and Smart 2007; Sharman 2012). In contrast, others see them as fundamentally breeding and in turn being bred by secrecy and malfeasance, and having a destabilizing influence on the global economy (Baker 2005; Palan et al. 2010; Shaxson 2011). Beyond their normative disagreements, these arguments imply intertwined yet distinct 
mechanisms through which OJs facilitate the exercise of power, one involving a manipulation of the rule of law which obeys its letter, and the other an undermining of rule of law via financial secrecy. Roberts (1994) describes this dichotomy in terms of fictitious versus furtive capital.

These questions are particularly salient in the context of developing and post-communist transition economies. While many have argued that the use of OJs by actors in these economies is related to poor domestic governance and institutional quality, conflicting interpretations exist as to whether OJs exacerbate or compensate for these problems. Some view offshore activity primarily as a mechanism for political insiders to hide the proceeds of corruption and state asset theft, and for wealthy individuals and firms to deprive developing economies and governments of desperately needed investment capital and tax revenue (Baker 2005; Brovkin 2001; Ding 2000; Oxfam 2000; Shaxson 2011). In contrast, others downplay these factors, arguing that OJs augment the competiveness of emerging market firms by allowing them to harness stronger overseas financial and legal institutions, often by facilitating overseas listings (Sharman 2012; Stal and Cuervo-Cazurra 2011; Sutherland and Matthews 2009). Clearly all of these motivations and effects come into play in various situations; however, we know little about their relative importance, even in the context of the most heavily studied cases such as China (Vlcek 2013). A problematic aspect of both sides of this debate is that they imply a divergence in offshore activity on the basis of national institutional characteristics which has been more assumed than demonstrated. To date, the strongest evidence for a general divergence between developing and developed economies relates to the role of the latter as suppliers of offshore services. The OECD economies are not only home to nearly all leading ABS firms, but occupy dominant positions as OJs (TJN 2012). This has complicated recent initiatives by the OECD and other organizations targeting offshore tax evasion and money laundering, with evidence 
suggesting that OECD investors increasingly prefer to use ostensibly respectable OECD OJs to reduce home economy legal and reputational risks (Eden and Kudrle 2005; Haberly and Wójcik 2014; Vlcek 2007). Ironically, this OECD offshore "club" effect (Haberly and Wójcik 2014) appears to have occurred even as many non-OECD OJs have implemented increasing regulation to boost their reputations (Sharman 2005), with some (e.g. the Cayman Islands) being shown to exercise stronger due diligence against activities such as money laundering and terrorist financing than most OECD OJs (e.g. Delaware) (Findley et al. 2012). As such, the implications of a preference for OECD OJs are difficult to interpret from a governance perspective. Analyses of tax treaties are likewise mixed regarding whether the discouragement of illicit investment by information sharing tends to be outweighed by the attraction of licit investment (Blonigen and Davies 2004; Haberly and Wójcik 2014; Rawlings 2007; Weyzig 2012).

That research on offshore finance has produced a picture that is in many respects detailed, yet at the same time largely incoherent, can be attributed in part to an inadequate basis for adjudication between competing perspectives. There is a wealth of case studies of offshore centers (Christensen and Hampton 1999; Cobb 1998; Roberts 1994; Sharman 2005; Warf 2000), and to a lesser extent their use by particular actors (Sutherland and Matthews 2009; Ting 2014; Walter and Howie 2011). At the global level, moreover, OJ rankings have been produced based on characteristics such as total assets or secrecy provision (TJN 2012). What we are mostly missing, however, is an empirically grounded understanding of the global relational architecture within which OJs are situated. Influential claims about the parameters of this architecture, such as the importance of post-colonial networks, or longitudinal belts reflecting time zone frictions to communication, rest on shaky foundations. In a reflection of this dearth of empirics, the time zone-based map of Roberts (1994) continues to appear in Global Shift (Dicken 2011), despite 
being nearly two decades old, and never having been rigorously verified. From the standpoint of operationalizing a "global wealth chain" or "global financial network" framework, establishing a substantiated outline of global offshore network organization is a crucial starting point.

Two general approaches could be taken to this. The first is to look past the fiction of offshore capital itself, rather applying world city research inspired methods to the examination of networks of ABS providers and users in onshore and offshore jurisdictions. Here, however, we take a different approach, problematizing the fictions of the offshore world as a legal-contractual reality in their own right. The principal building blocks of these fictions are Investment Vehicles (IVs), or shell companies as they are widely known (Coates and Rafferty 2007; Coe et al. 2014; Wójcik 2013a). These take a variety of forms including trusts, international business companies (IBCs), and holding companies. What they have in common, however, is their dissociation of the legal geography of capital from that of ultimate assets, owners, and or management, in the interests of tax and regulatory arbitrage and or secrecy enhancement. Aspects of IV activity may be recorded as either international portfolio investment (IPI) or foreign direct investment (FDI). Since 2002, the IMF has released a worldwide dataset of bilateral IPI stocks, the Coordinated Portfolio Investment Survey (CPIS), making it possible to examine the relational linkages of offshore IVs engaged in securities purchase or issuance, for example SPV "shadow-banks." Coates and Rafferty (2007) have conducted the only detailed network analysis of CPIS linkages focusing on OJs, which found that Luxembourg, the Netherlands, the Cayman Islands and Ireland are the most important offshore IPI nodes.

Whereas IPI data mostly highlights arms-length relationships, FDI reflects the networks of control into which IVs are inserted. The geography of these is often extremely complex, with IVs organized into multijurisdictional chains serving as captive financial systems for wealthy 
individuals and multinational corporations (Haberly and Wójcik 2014). There are incentives for these to be as complex as possible, as this maximizes the potential for jurisdictional arbitrage, and or the levels of secrecy that can be achieved. Such networks are typically designed to easily shift funds between jurisdictions, usually to those with the lowest tax rates, through "transfer mispricing," i.e. the valuation of intra-firm transactions at non-market rates (Palan et al. 2010; Sikka and Willmott 2010). While "offshore FDI" comprising these networks has been estimated to account for a third of all FDI (Palan et al. 2010), this fails to convey the pervasive extent to which FDI has become intertwined with and contorted by these accounting strategies (see figure 1). This has been facilitated by, and in turn encouraged the "knowledge economy" attribution of earnings to IP assets without a clearly defined territoriality (Seabrooke and Wigan 2014).

A small number of studies have examined offshore FDI by German (Weichenrieder and Mintz 2006), American (Lewellen and Robinson 2013; Desai et al. 2004), and BRIC economy firms (Ledyaeva et. al. 2013; Sharman 2012; Stal and Cuervo-Cazurra 2011; Sutherland and Matthews 2009; Vlcek 2013). These have revealed important structures, notably the centrality of the Netherlands as a tax "treaty-shopping" jurisdiction for OECD firms (also see Weyzig 2013), and large-scale "round-trip" FDI (for poorly understood reasons, see p. 9) by Chinese, Russian, and Indian firms in their home economies via Hong Kong, Cyprus, and Mauritius respectively, and the Caribbean. Since 2011, moreover, the IMF has released the first (and to date only) worldwide dataset of bilateral FDI stocks, the Coordinated Direct Investment Survey (CDIS), allowing research to be conducted on offshore FDI at the global level. Using CDIS data, Haberly and Wójcik (2014) conduct the first worldwide regression analysis of the determinants of bilateral FDI by OJs in "real" economies. The results indicated that offshore FDI was sensitive to physical proximity and shared colonial history, but not time zone proximity. 
Meanwhile, no evidence was found for variation in the level of inward offshore FDI on the basis of economic or institutional development or communist history, although evidence was found of elevated offshore FDI by OECD OJs in OECD hosts, as well as between tax treaty signatories.

While regression analysis allows for relationships to be rigorously tested, it can only provide yes/no answers to a-priori formulated hypotheses represented through quantifiable variables, and as such may not convey key aspects of offshore financial network organization. In contrast, a simple map will not afford the same level of rigor in testing specific hypotheses, yet is likely to be more effective at capturing and conveying dominant organizational characteristics. Most importantly, it is capable of revealing effects which are not a-priori anticipated, are resistant to quantification, and or exhibit inconsistent geographies of influence.

Here we employ principal component analysis (PCA) to construct the first global map of offshore FDI. Beyond simply displaying network structures, PCA allows us to decompose these into orthogonal constituent sub-networks, revealing key patterns which would not otherwise be visible. In examining these, we seek to answer three questions. Firstly, how globalized is the offshore FDI network — are all economies strongly tied to a common global core of OJs, or does the network exhibit a high degree of internal differentiation? Secondly, to the extent that the global network is internally differentiated, what is the structure of its principal sub-networks, in terms of both the offshore and onshore economies they encompass? Thirdly, what does the geography of these networks tell us about technological, institutional, political, and relational factors impacting offshore finance? The first two questions are addressed directly through PCA in section 4; in section 5 we address question three via an analysis of the patterns revealed in section 4 , supported by regression tests conducted to confirm the existence of subtle patterns. 


\section{Data and methodology}

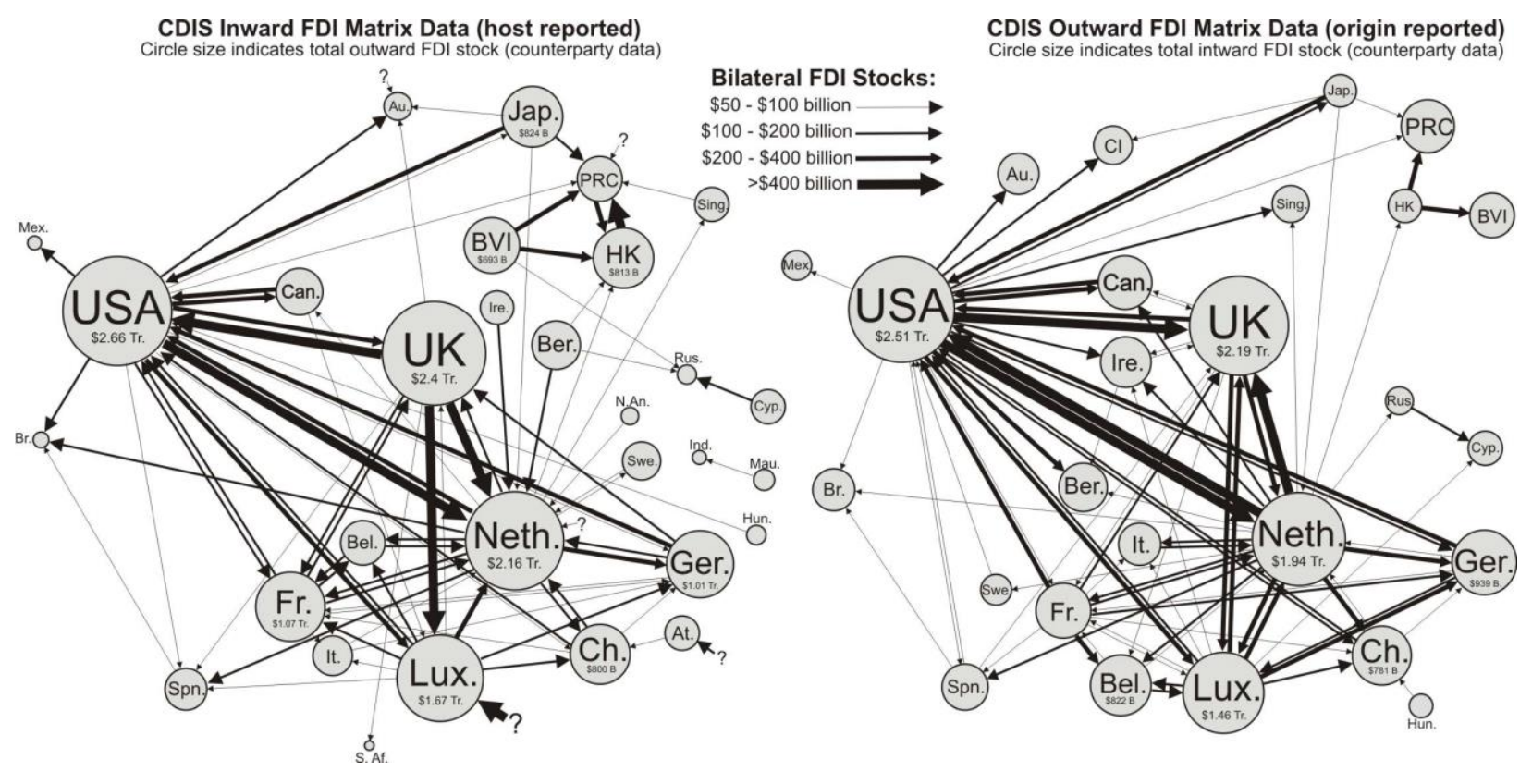

Figure 1. FDI Stocks $>\$ 50$ billion, YE-2010 (adapted from Haberly and Wójcik, 2014)

The IMF Coordinated Direct Investment Survey (CDIS) consists of two bilateral FDI

stock matrices, one containing inward FDI data reported by 83 hosts for 245 origin

counterparties, and the second containing outward FDI data reported by 67 origins for 245 host

counterparties. Figure 1 shows all bilateral FDI positions $>50$ billion USD for both matrices.

Two aspects of the data are striking. The first is the lack of an association between GDP and

FDI stock, with offshore FDI clearly not being a peripheral distortion of the FDI network, but

rather the predominant form of FDI. At the center of the network are four jurisdictions with

similar FDI positions; the US, UK, Netherlands, and Luxembourg. The second notable features

of the data are the discrepancies between host and origin reporting. In some cases, these result

from sample differences. China and Singapore, for example, participated in the inward, but not

outward CDIS, while many important OJs (e.g. BVI, Bermuda) participated in neither, meaning

that only unidirectional host/origin counterparty data is available for these in each matrix. In

many cases, however, governments report radically different figures for the same FDI position; 
while Ireland, for example, reports $\$ 19$ billion of inward US FDI, the US reports a figure of $\$ 158$ billion. These discrepancies appear to provide a window into the mechanics of offshore jurisdictional arbitrage, which largely rests on divergent definitions of nationality and residence.

While the CDIS contains an unprecedented wealth of information on global offshore FDI, its analysis is hindered by the fact that values only appear accurate to within perhaps an order of magnitude, as well as the sheer scale of the CDIS, with the host-reported matrix alone containing over 18,000 country pairs. What is needed is an analytical tool capable of extracting general patterns from this vast quantity of data, while abstracting from the somewhat dubious individual figures. Principal Component Analysis (PCA) is highly suitable in this respect. PCA is a statistical data compression technique, which represents the largest possible percentage of variance in a high-dimensional dataset, using the smallest possible number of new dimensions (components). In the simplest example, most of the information in two highly correlated variables could be captured by one component roughly following the trend line in a scatterplot of the two variables. In most cases, however, PCA is used to extract the core features of datasets with more dimensions than can be visualized. Its applications fall into two categories. The first is the extraction of common factors underlying a list of variables. Vyas and Kumaranayake (2006), for example, extract an underlying "socioeconomic status" dimension from household lifestyle indicators. Meanwhile, in the second class of applications, PCA used to analyze the distribution of a single indicator within a matrix wherein one dimension (i.e. rows vs. columns) is classified for the purpose of analysis as variables, while another is classified as observations.

This study falls into the second class of applications, using PCA to reduce the complexity of a matrix of bilateral economic relationships, a technique explored by Taylor (2004) in the analysis of world city network structure. We apply PCA to bilateral FDI "anomaly" data derived 
from the 2010 CDIS. FDI anomalies are designed to capture the "offshoreness" of FDI linkages, in the absence of a clear distinction between onshore and offshore jurisdictions. Anomalies are defined as a multiple of the bilateral FDI expected based on a partial gravity function, in which global FDI is assumed to be allocated in proportion to the product of origin and host nominal GDP sizes. This transformation is founded on the IMF's heuristic definition of an offshore center as "a country or jurisdiction that provides financial services to non-residents on a scale that is incommensurate with the size and financing of its domestic economy" (Zorome 2007, pp. 12-13). The association of total outward FDI anomalies (outward FDI/GDP) with tax haven status can be seen in Appendix $1^{2}$. By examining bilateral rather than jurisdictional anomalies, our analysis refines the IMF rubric to reflect the relational nature of offshore finance. FDI anomalies are log-transformed ${ }^{3}$ to achieve a normal distribution, which has the added benefit of rendering PCA results relatively robust to the large margin of error of the CDIS data.

The discrepancies between the CDIS inward and outward FDI matrices mean that there is no effective way to combine them; we only use the host-reported inward FDI matrix (see figure 1), which has superior coverage. ${ }^{4}$ We classify hosts as variables, and origins as observations. ${ }^{5}$ Several OECD hosts share a correlated pattern of missing influential values, which if uncorrected produces a spurious component. In most cases, gaps could be filled with OECD data on the

\footnotetext{
${ }^{2} \log ($ outwardFDI/GDP) and tax haven score (derived from table 1.4 in Palan et al. 2010) have a correlation of 0.54

${ }^{3}$ Zero values present a challenge in this respect; we use an if-then statement to force zero values to zero in the $\log$ transformed matrix. Maintaining zero values in this manner requires us to apply a large multiplier to all anomalies before log-transformation, to prevent anomalies smaller than 1 from assuming negative values.

${ }^{4}$ The origin-reported matrix excludes many important economies such as China, Singapore, Indonesia and Nigeria.

${ }^{5}$ The fact that the CDIS reports data on a larger number of origins than hosts means that the reverse assignment of variables/observations may produce poor PCA results (McCallum et al. 1999).
} 
bilateral FDI of member states (which closely matches IMF data), in some cases from 2009 or 2011. It was impossible to adequately repair inward FDI data for Spain, Portugal, Switzerland, Luxembourg, Australia, Bosnia, and Bhutan, which had to be dropped as hosts. ${ }^{6}$ The KMO test of sampling adequacy for the 76 hosts retained is 0.94 , indicating high PCA suitability.

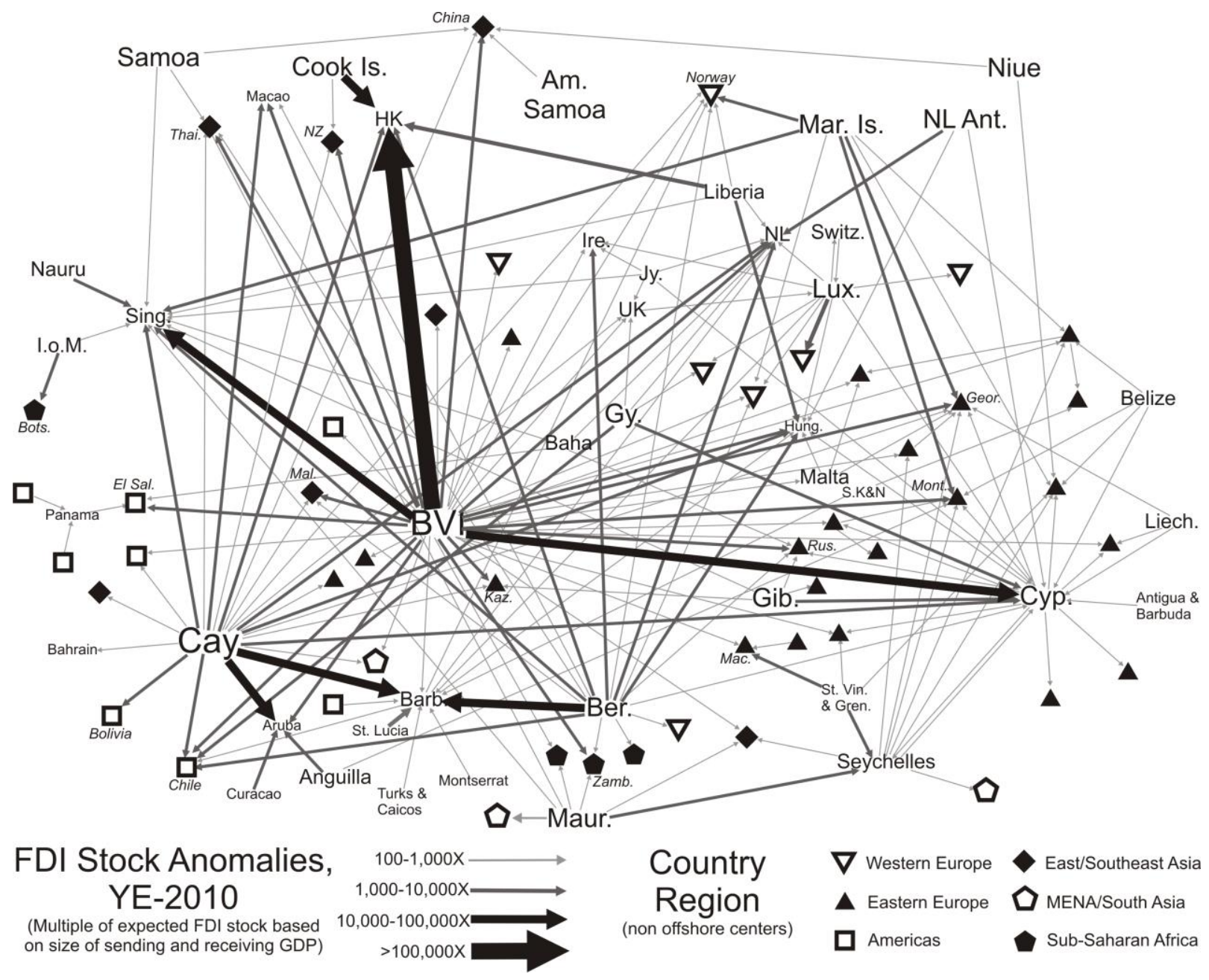

\section{Figure 2. Bilateral FDI stock anomalies, YE-2010 (source: IMF CDIS, inward FDI matrix)}

Figure 2 shows the largest FDI anomalies in the CDIS inward FDI matrix. Dominating the center is what could be described as a Caribbean offshore financial "Bermuda Triangle"

\footnotetext{
${ }^{6}$ This was decided on the basis of a host PCA suitability index calculated as the sum of total outward FDI anomalies (outward FDI/GDP) for each missing origin counterparty, divided by the sum of total FDI anomalies of all origins. Host economies with an index $<50 \%$ were retained; in only two retained cases was the index $>20 \%$.
} 
consisting of Bermuda, the Caymans, and BVI. Other major OJs, including Cyprus, Mauritius, and Luxembourg, also stand out prominently. The PCA results can be conceptualized as bundles of the (log-transformed) FDI anomalies visible in the figure, correlated across groups of hosts. Although the analysis is quantitative, the results should be seen as qualitative, providing a general map of offshore FDI network structures. While the use of FDI anomalies weights the analysis towards "offshore" structures, "real" FDI (to the extent that this is a meaningful concept) is still incorporated into the analysis, allowing it to capture the relationship between onshore and offshore network elements. This information may also shed light on the nationality of investors using OJs, although the results primarily identify the major offshore "pipelines" channeling capital into economies, without definitively revealing the identity of this capital. More generally, while the CDIS provides the best picture of offshore FDI currently available, results should be treated as tentative in light of the limitations of the dataset discussed above.

\section{Mapping the global offshore FDI network}

PCA involves two successive algorithms, extraction and rotation. Extraction entails a successive selection of components (dimensions) such that each explains the greatest possible remaining variance in a dataset. Next, rotation adjusts the loadings of variables (host economies) onto a selected number of components such that each is as closely associated as possible with a single component, facilitating the visualization of the data space defined through extraction. To gain the most exhaustive possible understanding of FDI anomaly network structure, we employ a novel iterative rotation procedure. This incrementally increases the number of (varimax) rotated components, starting from the one-component solution generalizing network structure to the greatest extent possible, with each additional component allowing for the 
targeting of more specific network features. The addition of components yields diminishing returns, with the first explaining $41 \%$ of all variance in global FDI, and the next three together only explaining an additional 15\% (see figure 3 left). Subsequent components have little or no more explanatory power than benchmark components generated from random data ${ }^{7}$. As such, most of the variance within the global FDI anomaly matrix can be represented with four-to-five dimensions. Given that each additional component adds little to total explained variance, each can be thought of as a sub-network predominantly nested inside of the networks identified using smaller numbers of components, as shown in the "tree" diagram in figure 3.

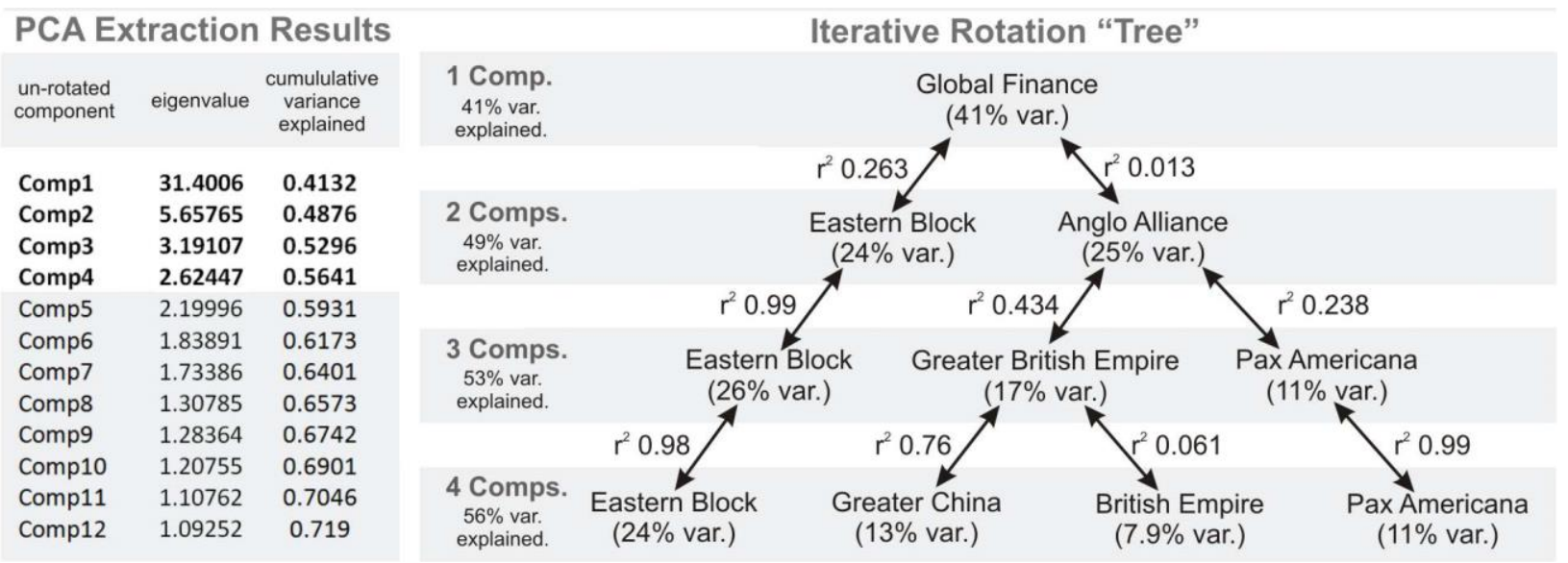

Figure 3. PCA results summary

At the highest level of generalization, all components can be seen as primarily nested within the one-component solution. The strengths of correlation (loading) of hosts with this "Global Finance" network are indicated by the shading in figure 4, with the standardized "scores" of FDI sources indicated by circle icons. An examination of highly scoring sources suggests that the methodology here effectively targets offshore FDI. Scoring highest is BVI, followed by Luxembourg, the Caymans, Netherlands, Switzerland and UK. Also scoring above

\footnotetext{
${ }^{7}$ This is based on parallel analysis (see Hayton et al. 2004). A fifth component had borderline meaningful explanatory power, but appears somewhat noisy visually, and conveys little additional information.
} 
2 are Bermuda, Cyprus, France, Germany, Liechtenstein, the US and Denmark (an important shell company OJ). In all, this component indicates that the offshore FDI network is highly centralized at the supply-side in northwest Europe and the "Bermuda Triangle." However, it is remarkably homogenous at the demand side. All major economies have loadings of between 0.1 and $0.2\left(\mathrm{r}^{2}\right)$, and most have loadings of between 0.15 and 0.2 . This indicates that the offshore FDI network is at its heart truly global, with countries having limited differentiation in engagement with it based on development, proximity, history, or other factors.
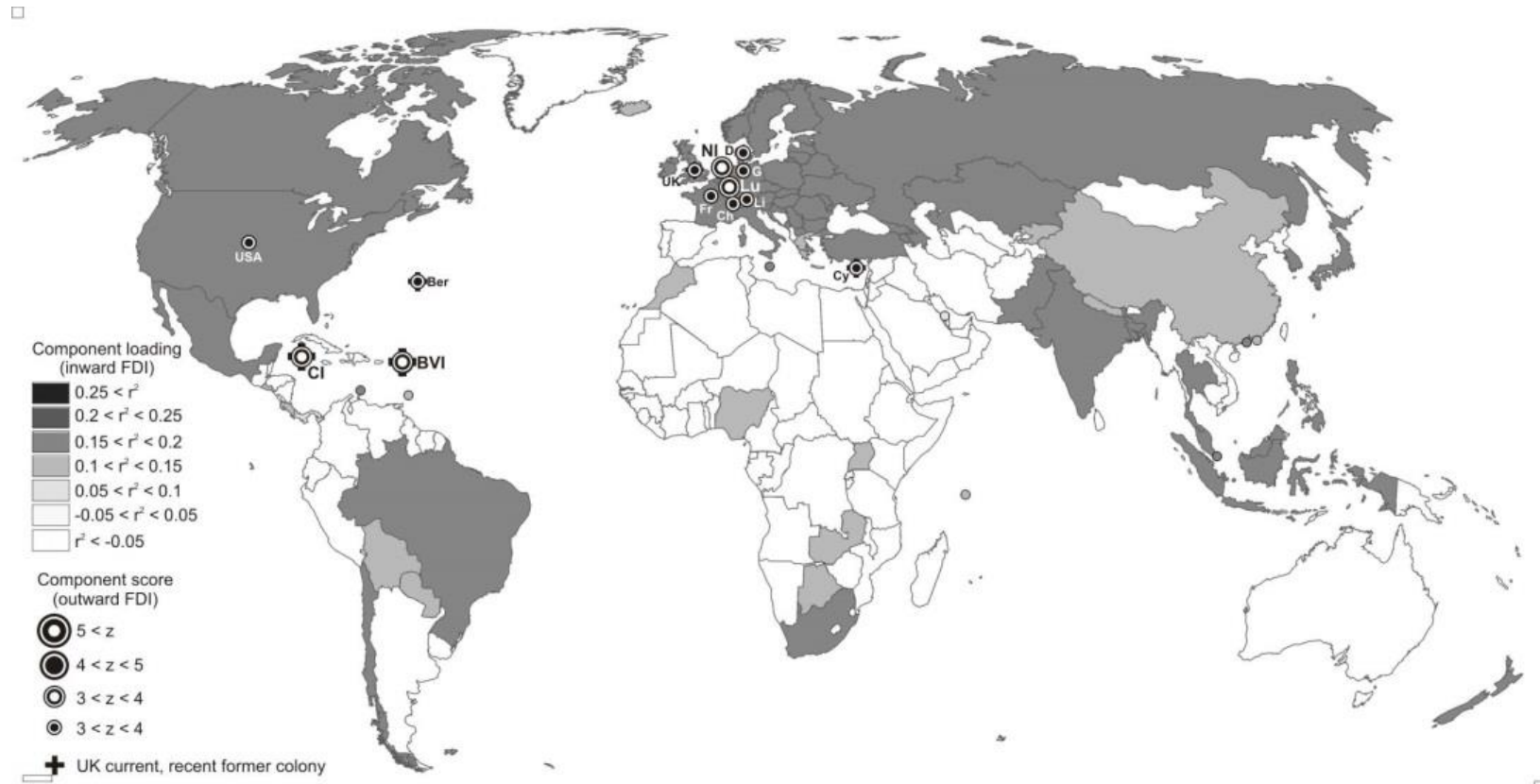

Figure 4. "Global Finance"

The global offshore FDI network is not entirely homogenous, however, and it is possible to dissect its structure by examining the lower tiers of the tree diagram in figure 3 . New components tend to branch off of specific "parents" as the number of components increases, with others being retained in a mostly unchanged form. As such, only six distinct dimensions of network differentiation can be identified within the PCA tree; the four sub-networks identified in the four-component rotation — what we have deemed the "Eastern Block," "Greater China," "Pax 
Americana," and "British Empire" components—and two "linking" networks into which these merge at higher levels of generalization, referred to as the "Greater British Empire" and "Anglo Alliance." In the following sections, we first examine each of the sub-networks identified by the four-component rotation, before turning to an analysis of the two linking sub-networks, and finally examining the relationships between all of these networks.
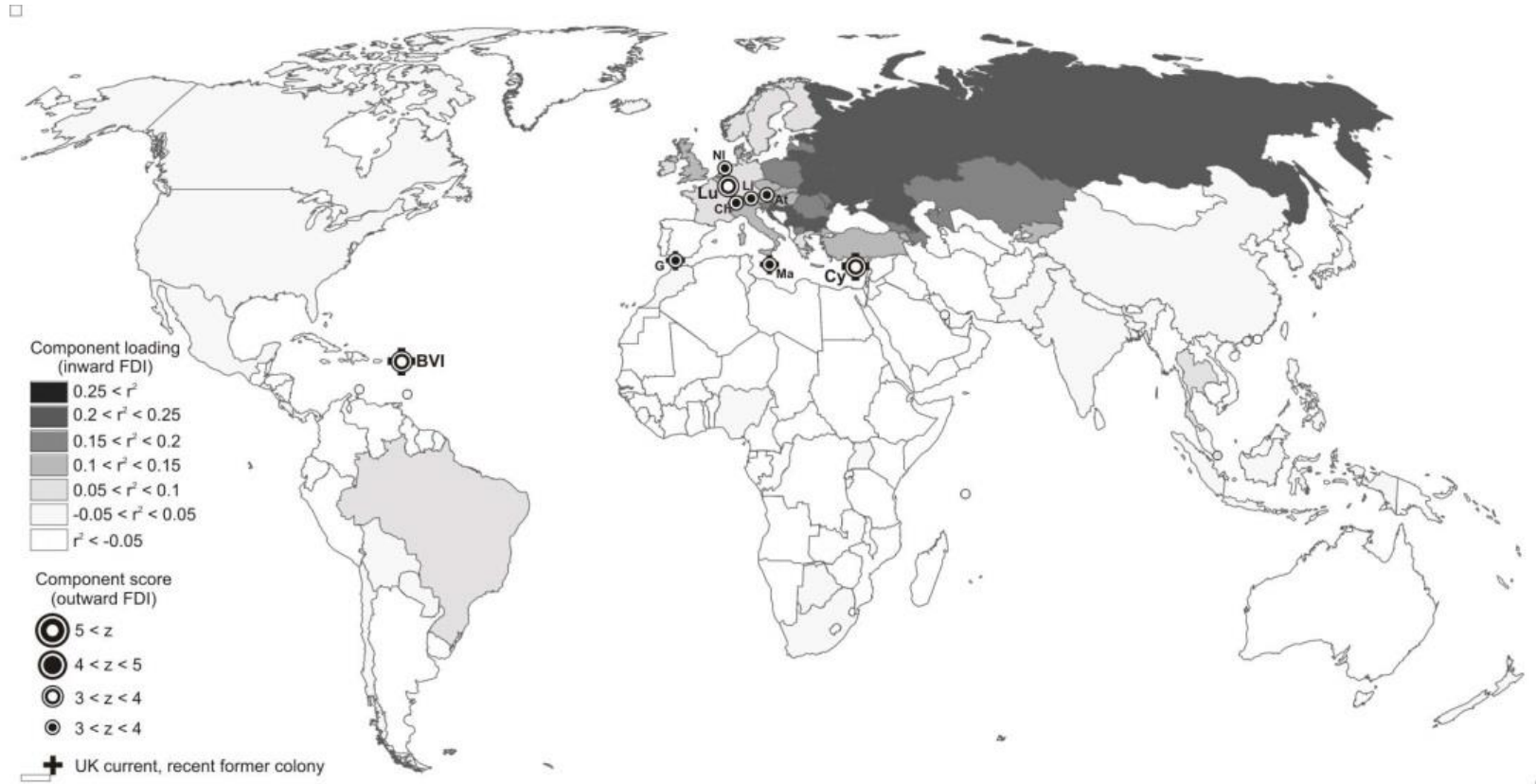

Figure 5. "Eastern Block"

The first rotated component highlights the Russia-Cyprus-BVI round-trip FDI circuit, as well as the Gibraltar and Liechtenstein branches of this structure, identified in previous research (La Franco and Sazonov 2013; Ledyaeva et. al. 2013). The results demonstrate that this structure is not uniquely Russian, however, with Russia rather one member of an "Eastern Block" network prominent enough to be visible at the right side of figure 2. This appears to follow what could be called a European geography of poor governance, with Belarus loading most strongly, followed by Ukraine, Montenegro, Bulgaria, Russia and Serbia. This matches well with the lowest scoring FSU/Eastern European countries on the World Governance Indicators Rule of Law Index 
(World Bank 2012)—on which Kyrgyzstan scores worst, followed by Belarus, Ukraine, Russia, Armenia, Albania, Serbia, Georgia, Bulgaria and Montenegro—-suggesting that this component is associated with some combination of organized crime activity, corruption, poorly managed privatizations, and capital flight/round-tripping associated with political risk.

Among FDI sources, Cyprus and BVI score most highly, demonstrating the importance of the BVI-Cyprus offshore axis to Eastern Europe as a whole. Two particularly opaque secrecy jurisdictions specializing in trusts, Gibraltar and Liechtenstein, also score highly, along with Malta, seen as a sort of auxiliary Cyprus, and Austria, with its extensive network of Eastern European banking operations. Three globally oriented OJs, Luxembourg, Switzerland, and the Netherlands, also rank highly. Interestingly, the UK does not score highly as an FDI source, although it does load relatively strongly as a host, suggesting that The City's recognized ties with Russia and Eastern Europe are mostly intermediated via the UK-linked OJs listed above.

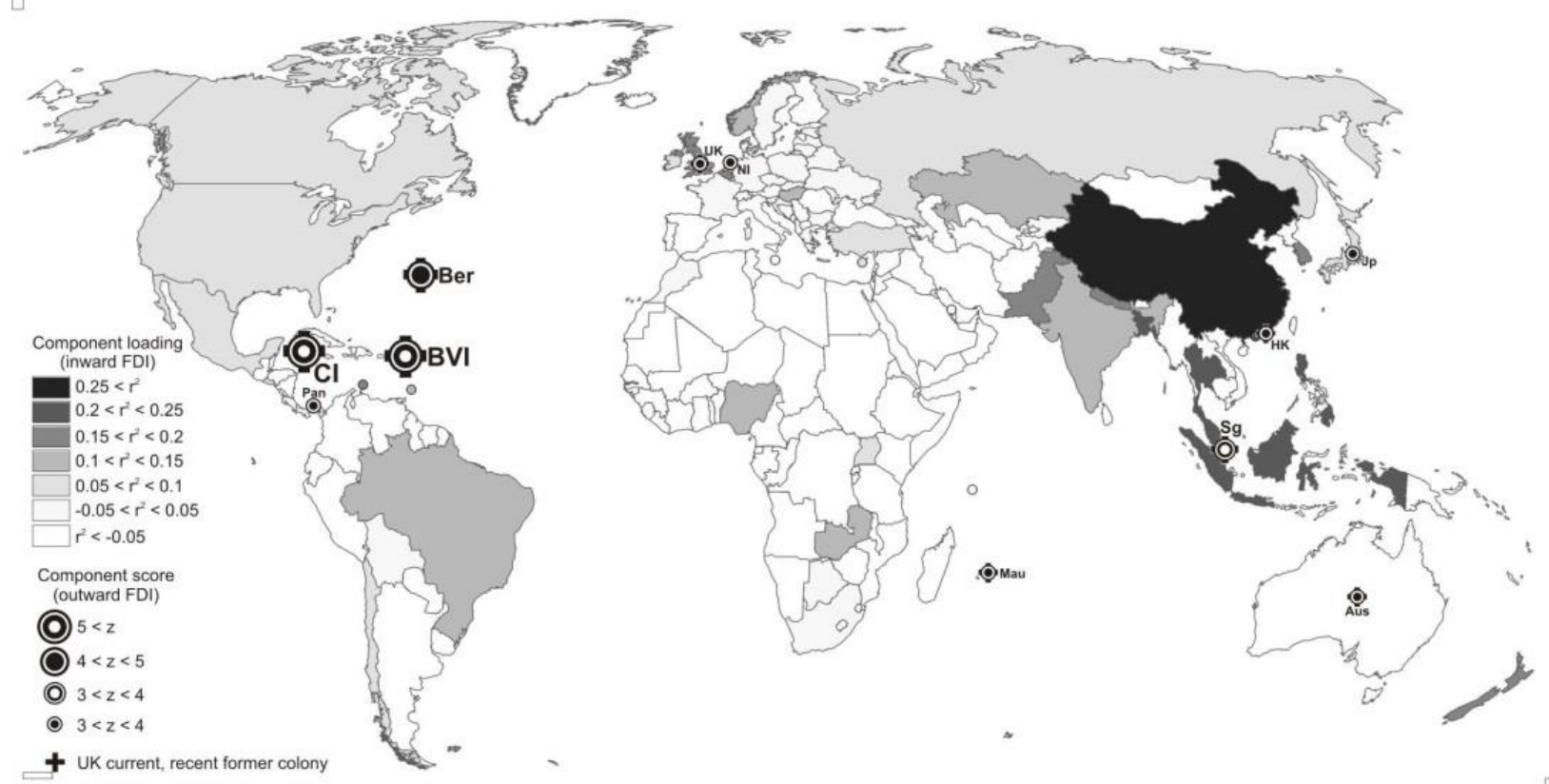

Figure 6. "Greater China" 
Just as the nucleus of component 1 is formed by the well-known Russia-Cyprus-BVI round trip FDI circuit, component 2 is centered on the even more important China-HK-BVI/CI circuit (Sharman 2012; Vlcek 2013). As for component 1, however, the PCA results indicate both that this is more of a regional than a country-specific structure, and that it contains a more complex array of OJ relationships than is widely recognized. Although the PRC, Hong Kong and Macao load most strongly onto this component, Singapore, the Philippines, Thailand, Indonesia, Malaysia, and Bangladesh are also strongly associated with it. The first five of these are significant for having economies largely dominated by ethnic Chinese business networks (Weidenbaum and Hughes 1996; Yeung 1999), suggesting that this component is most accurately understood as a "Greater China" offshore network. Dominating this at the outgoing FDI end are the "Bermuda Triangle" jurisdictions. BVI and the Caymans - both recognized centers of Chinese shell company formation, particularly for overseas listings (Sharman 2012; Sutherland and Matthew 2009; Vlcek 2013) — have exceptionally high scores of more than 5. Less recognized is link between China and Bermuda, which also serves as a leading incorporation jurisdiction for HK-listed units (Greguras et al. 2008). In addition to round-trip FDI, it is clear that large amounts of outside capital flow into "Greater China" through these OJs, although this is difficult to gauge precisely (Vlcek 2013). Within the Caribbean, Panama also scores highly, suggesting that it has stronger Asia-Pacific ties than is widely recognized.

Interestingly, component 2 is more strongly linked to UK colonial OJs than any of the others in the 4-component solution, with Singapore, Mauritius and the UK itself scoring highly alongside Hong Kong and the "Bermuda Triangle" OJs. Ironically, the transfer of Hong Kong to Chinese control seems to have pulled China into the orbit of Britain's financial "second empire." At the same time, the UK itself loads more strongly as an FDI host on this component than the 
other three, suggesting that Chinese offshore capital has in turn begun to have a major influence on The City. According to Bloomberg, PRC, Hong Kong, Malaysian and Singaporean investors accounted for $51 \%$ of new home purchases in central London in 2011 (Spillane 2012), a type of investment associated with the use of London financial services by wealthy clients. As will be discussed, the "Greater China" component can be situated within a "Greater British Empire" network spanning most of Africa and Asia.

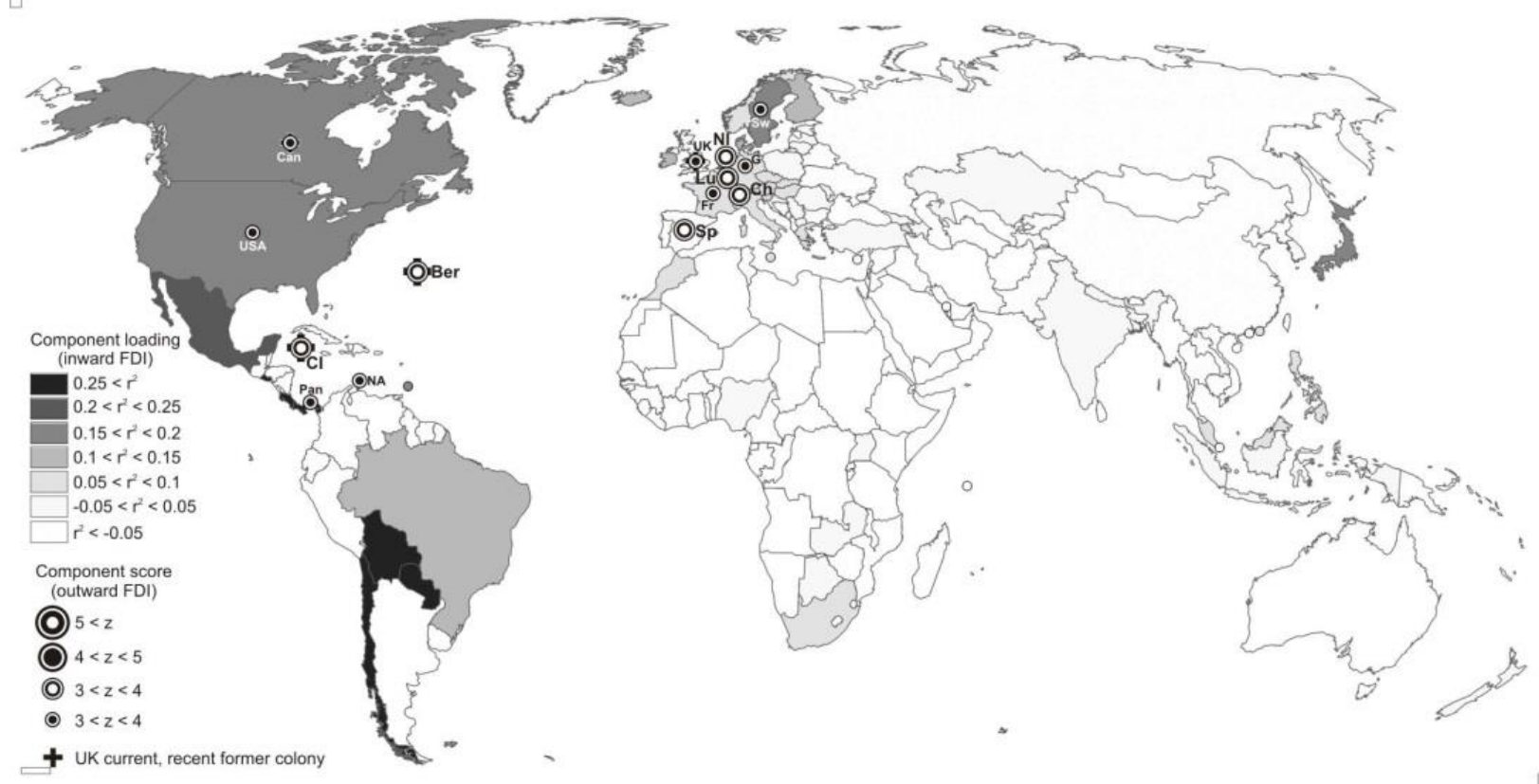

Figure 7. "Pax Americana"

In contrast to the previous two components, which are dominated by emerging market round-trip FDI, the third clearly corresponds to the US and its economic and political sphere of influence in Latin America, Western Europe, and Asia. Countries in the Americas load uniformly highly as hosts, with Latin America (apart from Brazil) loading highest. Outside of the Americas, Japan and Sweden have loadings higher than 0.15 , and are more strongly associated with this component than any other. Meanwhile, Iceland, the Netherlands, Finland, Ireland, and Denmark have $\mathrm{r}^{2}$ s greater than 0.10. Apart from Finland, these countries are 
significant platforms for American "offshore FDI," while Sweden possibly has links to American finance via its large private equity sector. Countries in Western Europe in general, along with the Philippines, Malaysia and South Africa, have moderate $r^{2}$ s greater than 0.05 .

To a greater extent than for the first and second components, it is difficult to disentangle whether host loadings on this component primarily reflect round-trip capital flows via OJs, or inward OJ-mediated investment by foreign, particularly American capital. Indeed, component 3 seems to constitute a "Pax Americana" network transcending the identity of the capital flowing through it. To a large extent, the OJs scoring highly as FDI sources do correspond to the jurisdictions of choice of US multinationals. This is particularly true in the Caribbean, where Bermuda, the Cayman Islands, and Netherlands Antilles score highly. BVI does not appear, reinforcing the impression that this is mostly an eastern hemisphere OJ. In general, however, FDI sources scoring highly on this component suggest more than a purely American driven pattern, with Luxembourg, the Netherlands and Switzerland scoring above 3, and the UK, France, Germany, Canada, and Sweden scoring above 2. This is a largely representative panel of OECD “midshore" jurisdictions for which offshore and real FDI are difficult to disentangle. Ireland is surprisingly absent, perhaps reflecting the data discrepancies discussed in section 3 . Latin American offshore activity appears to be difficult to disentangle from that of US and other OECD investors, with capital in the western hemisphere flowing between north and south through similar channels in both directions. Two of the OJs scoring highly, Panama and Spain, do appear to have characteristically Latin American fingerprints, however. Although Spain's role as an OJ for Latin America is not widely recognized, the combination of the dominance of Santander and BBVA in regional banking (Guillen and Tschoegel 2000), with 
Spain's \#11 worldwide ranking as an OJ driven by the private banking activities of these same two banks (TJN 2012; Henry 2012b), suggest that this role is quite important.

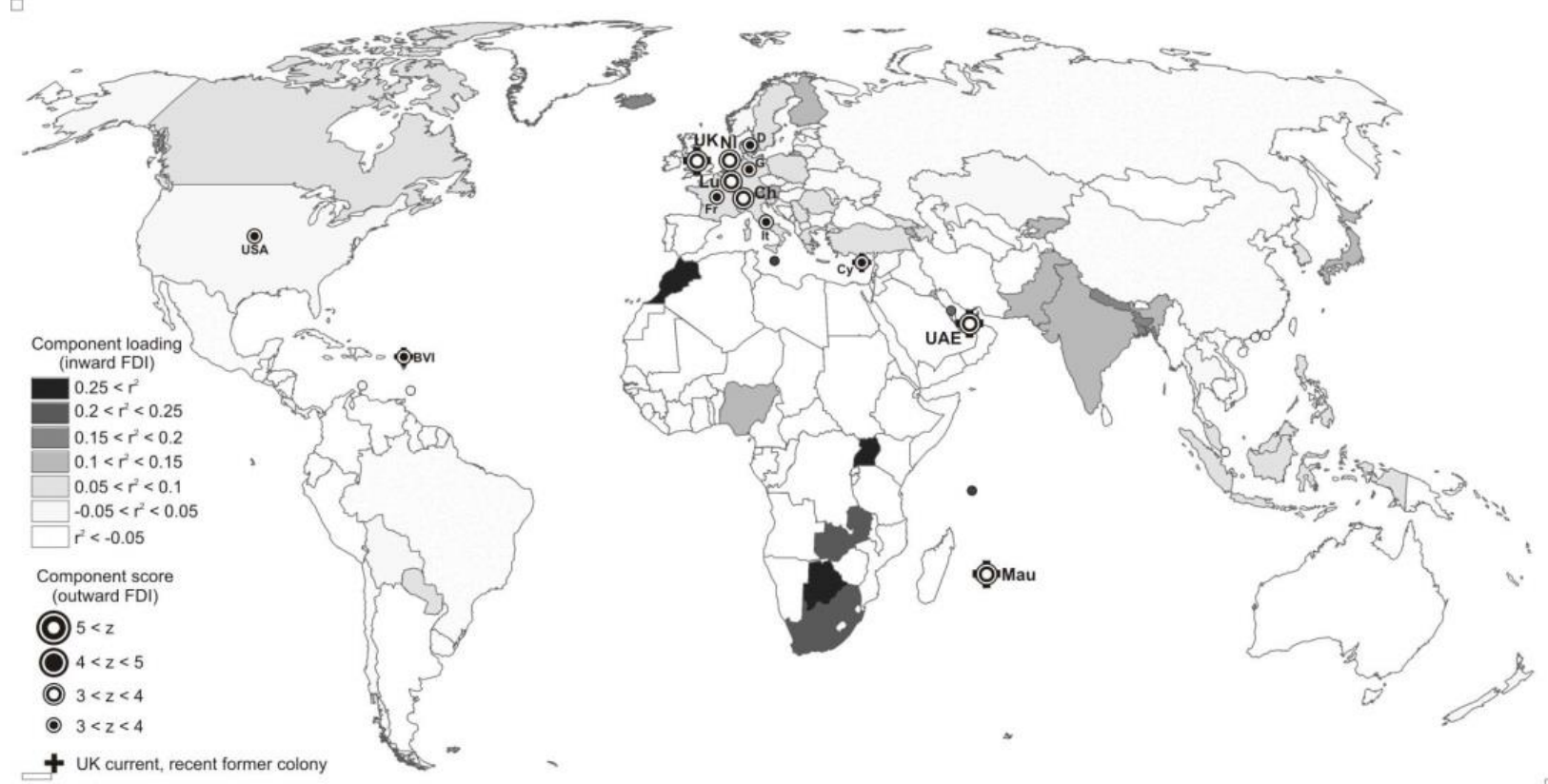

Figure 8. "British Empire"

Although somewhat blurry, the outlines of the former British Empire clearly define the fourth component. Former UK colonies Botswana, Uganda, Malta, the Seychelles, South Africa, and Zambia load strongly as hosts, with former colonies in South Asia and the Persian Gulf also loading relatively highly. While the association with UK colonization is strong overall, several countries without this history also load strongly, notably Morocco and Iceland, as well as Austria, Japan, Finland and Kyrgyzstan. Morocco's loading raises the question of whether the boundary between British and French post-colonial spheres of influence is eroding. The high loadings of Iceland and Austria likely reflect ties as OJs to City-dominated financial networks. Europe, Canada, and Southeast Asia show moderate loadings generally.

Among FDI sources, Luxembourg scores most highly, followed by the UK, which scores much more highly on this component than any other. Two global offshore FDI hubs, the 
Netherlands and Switzerland, also score above 3, as do two Indian Ocean rim OJs, the UAE and Mauritius. Mauritius scores higher on this component than on the "Greater China" network, in line with its reputation for specializing in the Africa and South Asia regions. Among UK colonial OJs, BVI and Cyprus also score highly, emphasizing the latter's importance as a financial center within the MENA region, in addition to Eastern Europe. Finally, the high scores of several major OECD economies—France, Germany, Italy, the United States and Denmarklikely reflect both "real" and offshore FDI links, and as for the host loadings perhaps a blurring with age of what are clearly still highly relevant former colonial spheres of financial influence.

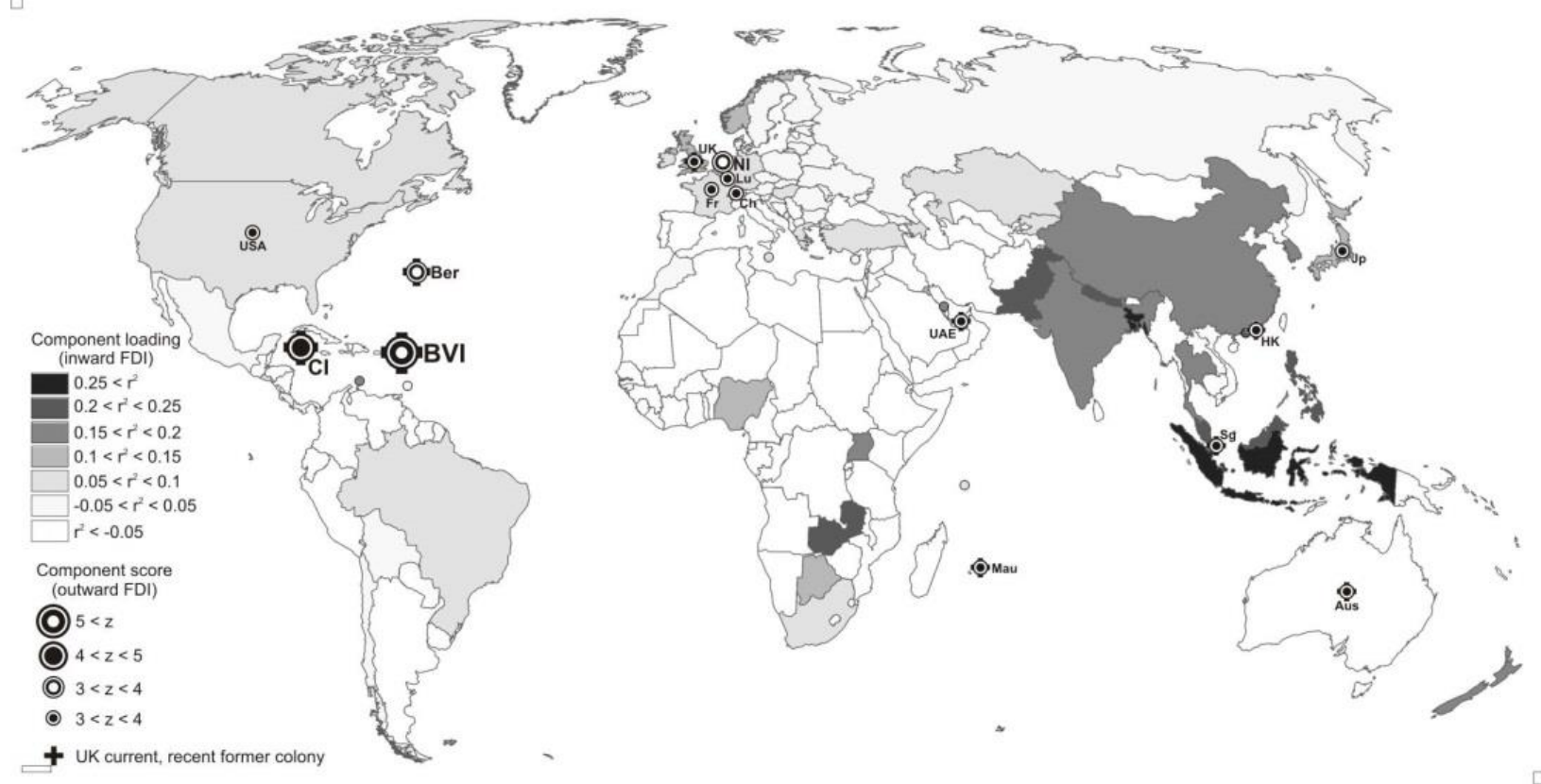

Figure 9. "Greater British Empire"

A comparison of the second and fourth components indicates that the boundary between them is weakly defined, with South Asia in particular being a zone of overlap. In fact, these components effectively merge in the three-component solution (see figure 9). The merged component is centered on the Indian Ocean core of the former British Empire, but also exerts an influence beyond former UK colonies to economies such as Indonesia and China. Regionally, 
the former UK colonial entrepots of Mauritius, the UAE, Hong Kong, and Singapore all score highly as FDI sources, as do the "Bermuda Triangle" jurisdictions, and several key offshore FDI hubs in Europe, including the UK itself. In all, the "Greater China" and "British Empire" networks appear to be most accurately described as gradations within an overarching "Greater British Empire" network, which intermediates a mixture of local and advanced economy capital.
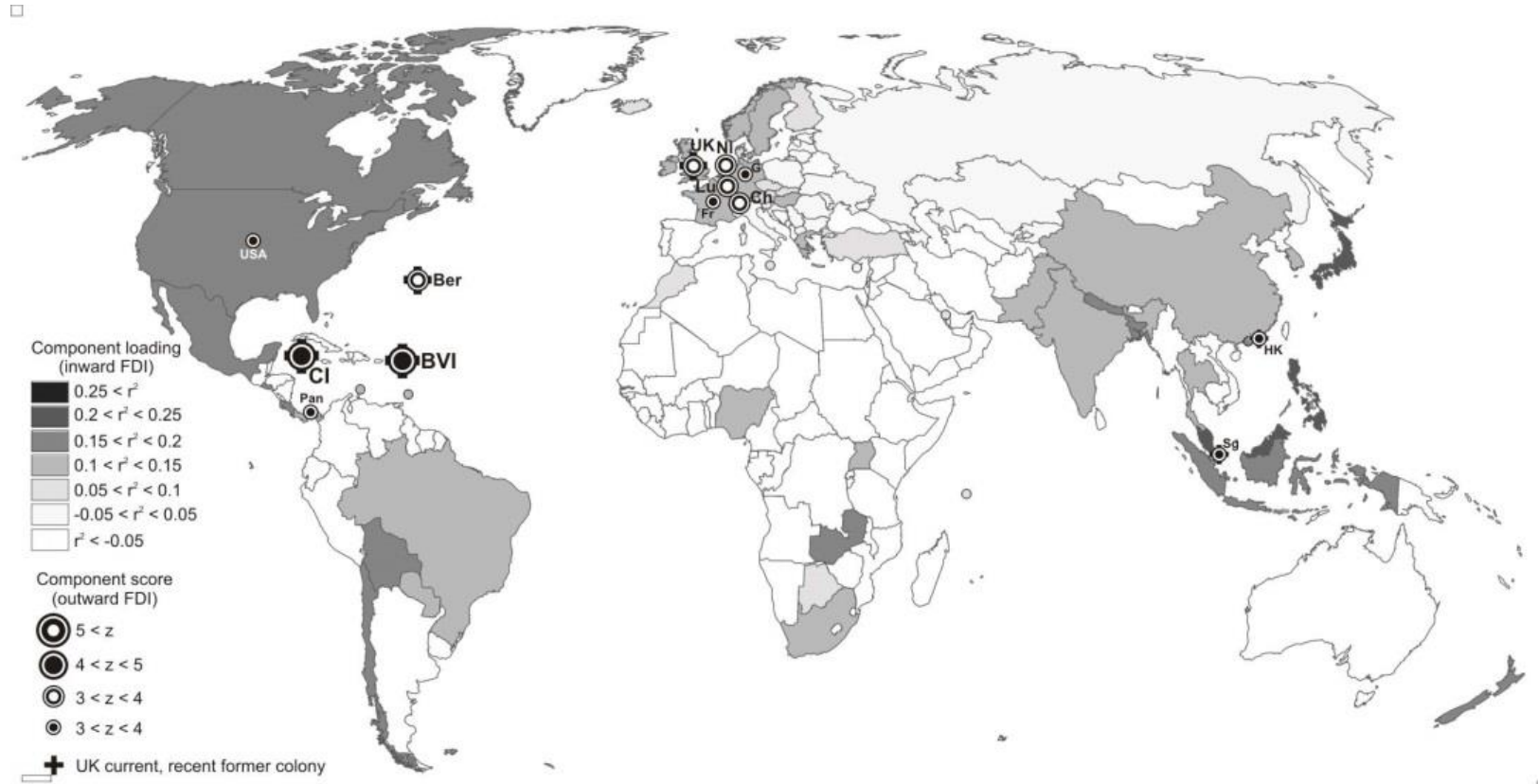

Figure 10. "Anglo Alliance"

At the two component level of resolution, the "Greater British Empire" network in turn merges with the "Pax Americana" network into what can be described as an "Anglo Alliance" network. At the host end, this essentially encompasses everything outside of the former communist Eastern Block, suggesting that the primary cleavage within the global offshore FDI network is between these countries and the rest of the world. At the FDI origin end, it comprises all of what Roberts (1994) described as the three major OJ clusters in the Caribbean, Europe, and East Asia, indicating that all of these exercise a substantial influence on each other's as opposed to simply within their own respective regional hinterlands. 

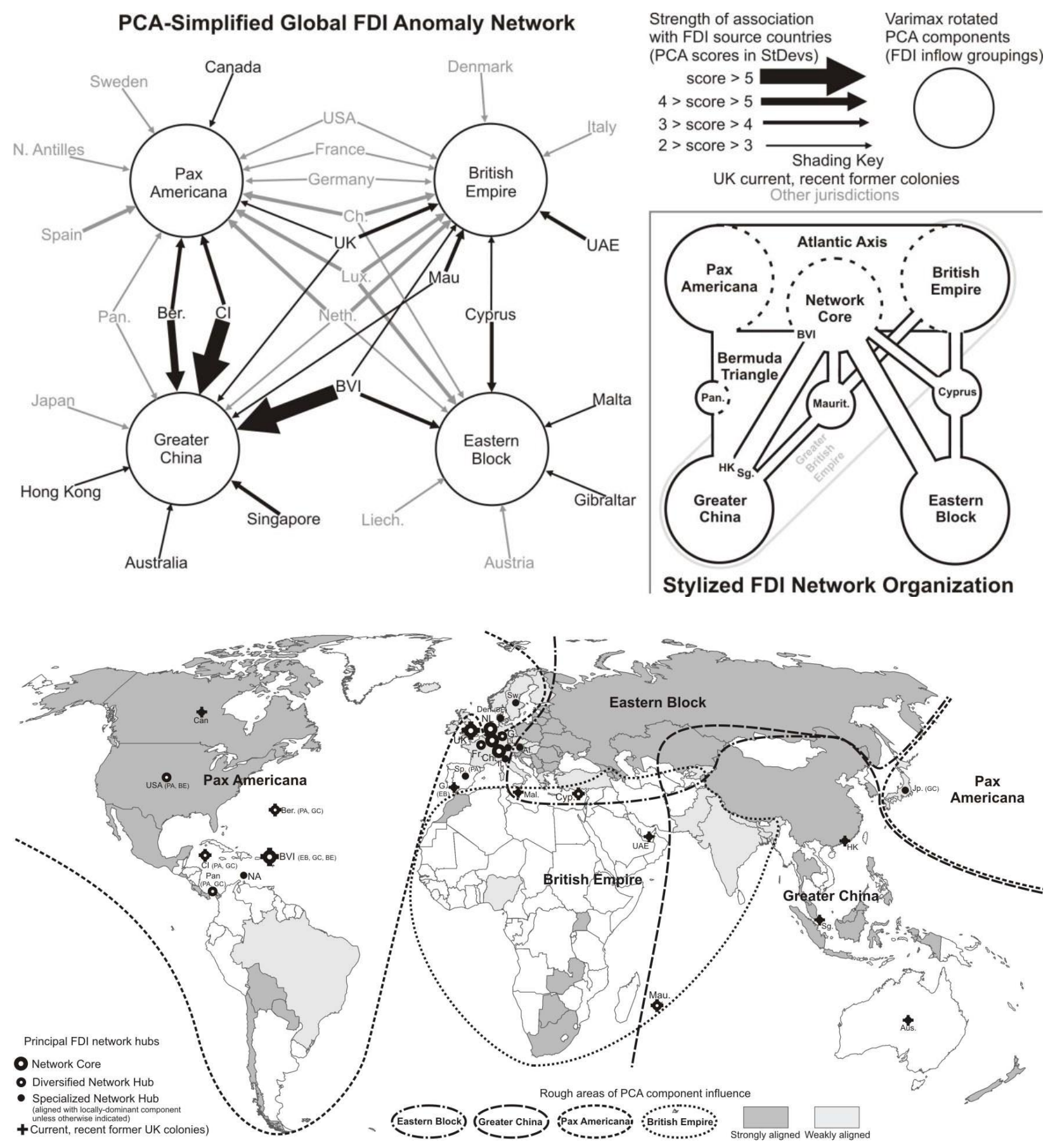

Figure 11. Global Offshore FDI Network Organization

As was noted earlier, the purpose of PCA is to simplify complex datasets to reveal key relationships within them. Figure 11 (top left) shows the commonalities between FDI sources scoring highly on each of the four PCA components, and can be understood as a simplified 
version of the network anomaly map shown in figure 2 . Three features, shown in the inset in stylized form, stand out prominently. Firstly, the Pax Americana and British Empire components exhibit the densest concentration of shared connections, being linked through the US, France and Germany, as well as the Netherlands, Luxembourg, UK and Switzerland. These are the leading OECD "midshore" jurisdictions, with each home to not only a large offshore financial sector, but a diversified array of multinational enterprises. There appears to be a direct correspondence between this "Atlantic Axis" of jurisdictions bridging the Pax Americana and British Empire components, and the situation of both within the overarching "Anglo Alliance" network.

Lying mostly within the "Atlantic Axis" is a global "Network Core" of jurisdictions linked to at least three of the four components, consisting of the Netherlands, Luxembourg, UK, Switzerland, and BVI. The first four constitute the more "offshore" of the midshore economies within the Atlantic Axis, with BVI being something of an outlier insofar as it is purely a booking rather than functional financial center, and not part of the Atlantic Axis. Within the Network Core, the Netherlands is the only jurisdiction linked to all four components, underscoring its status as the global FDI network's central hub. BVI is unusual, as it is relatively specialized towards a single component, Greater China, and only weakly connected to the Pax Americana component. It is also an oddity insofar as it lies outside of Northwest Europe, which as figure 11 (bottom) indicates is clearly the dominant geographic center of the global offshore FDI network. BVI in turn forms one vertex of the "Bermuda Triangle" dominating Caribbean offshore finance, with the Caymans and Bermuda forming the other two. Presumably there are large FDI flows between these OJs, but these are impossible to measure given that none participated in the CDIS. These jurisdictions serve as booking centers for enormous offshore capital flows, most importantly within and between the Pax Americana and Greater China networks, with BVI also 
having strong connections to the Eastern Block and British Empire. Panama, with strong ties to both the Americas and Greater China, can be seen as an extension of this structure.

Together, these three structures define the primary offshore "pipelines" within the global economy. Also standing out as important on the basis of the PCA analysis, however, are three secondary features. As has been noted, Cyprus is more important than has been generally appreciated during the Eurozone crisis, forming a key linkage between the British Empire, Eastern Block, and global Network Core. Another important network bridge is Mauritius, which arguably plays an analogous role to Cyprus in linking the Greater China and British Empire components to one another and the Network Core. Two final jurisdictions deserving particular mention are Hong Kong and Singapore, which serve as the financial gateways to Greater China. Strikingly, nearly all of these major hubs and gateways are current or former UK colonies, which account for two thirds of highly scoring FDI sources outside of Northwest Europe, and underscore the importance of Britain's offshore "second empire" (see figure 11).

\section{Determinants of offshore FDI network organization and evolution}

The offshore FDI network organization revealed by the PCA sheds light on debates regarding the organizational and evolutionary logic of offshore activity. The offshore FDI network is strongly globalized, with a well-defined core of jurisdictions in Western Europe and the Caribbean exhibiting a largely homogenous global footprint. This centralized structure, however, appears to be the product of a process of slow historical accretion, rather than being indicative of a fast-paced virtual global electronic marketplace constantly reshaped by regulatory shifts. The idea that offshore finance is organized into time zone blocks, linked to the imperative of instantaneous communications, is clearly not borne out. In the Old World, the major divide is 
between north ("Eastern Block") and south ("Greater British Empire"), not east and west, while Japan loads more strongly with the Americas than its neighbors. Moreover, the reach of OJs is both heterogeneous - with some serving global more than regional hinterlands—and seemingly influenced more by physical than time zone distance (corroborating Haberly and Wójcik 2014). The latter suggests an influence of long-term trust and face-to-face contact (i.e. travel).

Above all, the network structures appear to reflect a historical layering of social and political ties, with four processes and events standing out as most important: the establishment of global empires by European states, most importantly the UK, the shift in global economic and political hegemony from the UK to an Atlantic Axis of the US and its allies, the collapse of Soviet communism, and the rise of Chinese capitalism. With respect to the first, the metropolitan core of the former European imperial system is clearly the center of the network, with Britain's "second empire" of singular importance as a post-colonial structure. Acting as its principal nodes are an array of formerly, and in some cases currently UK-controlled entrepot city-states ringing the world's continents, typically established largely to control existing commercial networks - most importantly Arab, Indian and Chinese networks spanning the Indian Ocean and Southeast Asia. Although a mixture of local capital has once again become predominant within this region, the PCA results demonstrate that it continues to flow through this network of colonial strongpoints. Rather remarkably, this British financial empire does not seem to have displaced that of the previous economic hegemon, the Netherlands, but rather incorporated the latter as the central hub in the global offshore FDI network.

The second key historical influence on network organization was the shift during and after WWII of global economic and political hegemony from the UK to the US and its network of alliances, most importantly with the declining British Empire. While the PCA results show a 
general division between a US-dominated Western hemispheric offshore system, and a UKcolonial dominated Eastern hemispheric system, these share a broad "Atlantic Axis" composed of the US and major Western European "midshore" jurisdictions, which roughly corresponds to the Cold War Western alliance and adjacent neutral OJs. Indeed, the "Pax Americana" and "British Empire" components do not represent a sharp divide so much as two expressions of this axis, the global footprint of which is visible in the "Anglo-Alliance" component.

This narrative generally corroborates, while elaborating on, the historical-political accounts of Palan et al. (2010) and Shaxson (2011) of offshore network evolution. In contrast, the first and second components reveal structures and processes not hitherto recognized. While the activities of Russian investors in OJs such as Cyprus are well known, what has not been known is that these follow a stereotyped Eastern European pattern, likely produced largely by chaotic privatization programs in the 1990s. Meanwhile, the world's other major communist state, China, is clearly the rising engine of global offshore finance. Mirroring Russia, however, what has not been recognized is that the volume and pattern of PRC offshore FDI, passing in particular through the Caribbean, is part of a "Greater China" network encompassing regional overseas Chinese-dominated economies. The mainland, it seems, has become plugged into the offshore backbone of the regional "bamboo network" (Weidenbaum and Hughes 1996), with roots in $19^{\text {th }}$ century colonial labor and commercial policies, and older regional trading networks. Through this network, China has been drawn into the orbit of the UK's post-colonial offshore system — which in turn appears to have been increasingly drawn into the orbit of China. This highlights the question of whether China or other emerging economies will supplant the US as the leading source and destination of capital circulating through the UK's offshore archipelago; what does not seem to be in doubt, however, is the dominance of the archipelago itself. 
The PCA results are also relevant to debates regarding the institutional and regulatory dimensions of offshore finance. Although robustly detectable in regression (Haberly and Wójcik 2014), the OECD "offshore club" effect is apparently too subtle to be visible in the PCA results, being buried under the imprint of other factors. The most prominent divide in the offshore FDI network is rather defined by the legacy of communism and the cold war, with the Eastern Block sub-network strongly differentiated from the remainder of the global network. In addition to being a particularly distinct building block of the global network, this Eastern Block network exhibits unique institutional characteristics, specifically an association with weak rule of law. Moreover, a comparison of figure 5 to 6-11 indicates an unusually strong preference for physically proximate OJs, suggesting that the relational embeddedness of offshore ties may be conditioned by rule of law and communist history in a three-dimensional interaction relationship.

Further tests are necessary to confirm this. Table 2 shows the results of Poisson quasimaximum likelihood regression tests, using a gravity model specification with the same YE2010 CDIS dataset as the PCA, of these hypothesized interaction effects. The data, variable selection and methodology follow Haberly and Wójcik (2014), and test the determinants of bilateral FDI by a list of OJs derived from table 1 in Palan et al. (2010), in non-offshore hosts, using origin fixed effects dummy variables and "host control" variables. ${ }^{8}$ All models are identical to model 2.2.2 $2^{9}$ in Haberly and Wójcik (2014) except as follows. Firstly, all models test an interaction term multiplying $\log$ (origin-host distance) with host rule of law. Secondly, models 1.3-1.8 disaggregate the host economy sample according to communist history to test for variations in FDI determinants on this basis, with China variously included in the communist or

\footnotetext{
${ }^{8}$ These assume the average host value of a bilateral relationship variable (see Haberly and Wójcik 2014).

${ }^{9}$ This uses the $>50 \%$ expert agreement definition of OJs, based on table 1 from Palan et al. (2010).
} 
non-communist samples and dummy variables for sensitivity analysis to determine its

classification. The principal test variables are in bold, with others included primarily as controls and for comparability of results with Haberly and Wójcik (2014).

Table 1. Interaction effects between distance, communist history, and rule of law

\begin{tabular}{|c|c|c|c|c|c|c|c|c|}
\hline \multirow[b]{3}{*}{ Model } & \multicolumn{2}{|c|}{ All Hosts } & \multicolumn{3}{|c|}{ Communist Hosts } & \multicolumn{3}{|c|}{ Non-Communist Hosts } \\
\hline & & & Ex China & Inc China & Inc China & Ex China & Inc China & Inc China \\
\hline & 1.1 & 1.2 & 1.3 & 1.4 & 1.5 & 1.6 & 1.7 & 1.8 \\
\hline Pseudo r2 & 0.85 & 0.85 & 0.93 & 0.96 & 0.97 & 0.85 & 0.84 & 0.88 \\
\hline Sample Size & 2547 & 2547 & 941 & 982 & 982 & 1907 & 1948 & 1948 \\
\hline $\log (G D P)$ (host) & $0.96^{* * * *}$ & $0.95^{* * * *}$ & $1.57^{* * * *}$ & $1.17^{* * * *}$ & $1.60 * * * *$ & $0.79 * * * *$ & $0.98 * * * *$ & $0.79 * * * *$ \\
\hline Log(GDP/cap) (host) & -0.49 & -0.41 & 0.23 & -1.85 & -0.24 & $-0.90 * *$ & -0.3 & $-0.86 * *$ \\
\hline Log(distance) & $-0.66 * * * *$ & $-0.67 * * * *$ & $-1.27 * * *$ & $-1.70 * * * *$ & $-1.97 * * * *$ & $-0.90 * * * *$ & $-0.47^{*}$ & $-0.90 * * * *$ \\
\hline Log(distance) (host) & 0.49 & 0.58 & -0.33 & $-5.70 * * *$ & -0.084 & -0.12 & -0.096 & -0.088 \\
\hline Shared language & $-1.06 * * * *$ & $-1.05^{* * * *}$ & & & & -0.32 & $-0.52 *$ & $-0.44^{*}$ \\
\hline Shared language (host) & 0.45 & 0.26 & & & & 0.16 & 0.052 & 0.3 \\
\hline Colony-metro & $2.03 * * * *$ & $1.93 * * *$ & & & & $1.17^{*}$ & $2.44 * * * *$ & $1.57^{* *}$ \\
\hline Colony-metro (host) & $-4.01 * * * *$ & $-3.33^{* * * *}$ & & & & $-1.93^{* *}$ & $-3.66 * * * *$ & $-2.45 * * *$ \\
\hline EIA & $0.73^{*}$ & $0.72 *$ & $-1.41^{*}$ & -0.67 & -0.4 & 0.12 & 0.42 & 0.2 \\
\hline EIAs (host) & $3.95^{*}$ & 2 & -4.94 & -4.59 & $-7.39 * *$ & -2.91 & 0.76 & $-2.83^{*}$ \\
\hline EU & -0.5 & -0.48 & $1.71^{* *}$ & $2.15^{* * *}$ & $1.79 * *$ & $0.94 * *$ & 0.62 & $0.90 * *$ \\
\hline EU (host) & $-2.01 *$ & -1.06 & 1.34 & $3.51^{* *}$ & 2 & 1.32 & -0.24 & 1.26 \\
\hline OECD & $2.62 * * * *$ & $2.61 * * * *$ & $2.13 * * * *$ & $1.96 * * * *$ & $1.72 * * *$ & $2.12 * * * *$ & $3.18 * * * *$ & $2.58 * * * *$ \\
\hline OECD (host) & $-1.06^{* * *}$ & $-1.53^{* * * *}$ & -1.23 & $-3.09 * *$ & -1.57 & 0.075 & $-2.75^{* * * *}$ & -0.078 \\
\hline WTO & -0.26 & -0.32 & -0.046 & 0.79 & 0.8 & 0.58 & 0.73 & 0.72 \\
\hline WTO (host) & $-2.30 * *$ & $-1.70^{*}$ & 1.97 & $-3.78 * *$ & 0.6 & 0.78 & 1.09 & 0.81 \\
\hline Log(tax rate) (host) & -0.48 & 0.3 & -1.4 & $4.33^{*}$ & -0.61 & -0.29 & -0.59 & -0.25 \\
\hline Double taxation treaty & $1.18^{* *}$ & $1.10 *$ & 0.24 & 0.32 & 0.44 & $1.03^{* * *}$ & $1.16^{* *}$ & $1.03 * *$ \\
\hline DTTs (host) & 0.91 & -0.14 & 5.4 & $13.18^{*}$ & 6.75 & $-5.84 * * * *$ & -1.48 & $-5.60 * * * *$ \\
\hline No withholding tax & 0.43 & 0.33 & $1.49 * * * *$ & $2.01 * * * *$ & $1.80 * * * *$ & 0.15 & -0.52 & 0.12 \\
\hline No WH tax (host) & $1.27^{* * * *}$ & $1.30 * * * *$ & 0.68 & 0.5 & 0.69 & $2.19 * * * *$ & $1.47 * * * *$ & $2.18^{* * * *}$ \\
\hline Rule of law (host) & 0.52 & 0.93 & $-5.64 * *$ & $-6.41 * * *$ & $-5.81 * * *$ & -1.62 & 0.45 & -1.37 \\
\hline CFC rules (host) & -0.31 & -0.14 & $1.79 * *$ & 0.62 & $1.64 * *$ & $-1.13^{* *}$ & -0.78 & $-1.13^{* *}$ \\
\hline $\begin{array}{l}\text { Communism (excl. } \\
\text { China) (host) }\end{array}$ & -0.78 & & & & & & & \\
\hline Communism (host) & & 0.55 & & & & & & \\
\hline (rule law) x log(dist.) & -0.016 & -0.017 & $0.74 * *$ & $0.90 * * * *$ & $0.82 * * *$ & $0.46 * * *$ & 0.12 & $0.43^{* * *}$ \\
\hline China (host) & & & & & -8.03 & & & 0.91 \\
\hline China $\mathrm{x} \log ($ distance) & & & & & 0.46 & & & 0.43 \\
\hline Constant & 5.88 & 1.42 & 4.85 & $58.57 * * *$ & 10.21 & $14.88^{* *}$ & 5.73 & $13.77^{* *}$ \\
\hline
\end{tabular}

The results confirm the interaction effects suggested by the PCA results. As expected, the interaction of distance and host rule of law is significantly positive for the communist sample (with or without China, see below), indicating that the offshore FDI of hosts with lower rule of law is more sensitive to distance. The effect is large, with the expected offshore FDI of an economy with Russia's rule of law (-0.77) at least three-and-a-half times more sensitive to distance than that of that an economy with the rule of law of the Czech Republic (0.95). This 
effect, moreover, extends to non-communist hosts, although it is only half as powerful. ${ }^{10}$ The coefficients on host rule of law and $\log$ (distance) cannot be taken at face value, but must be understood as defining intercepts for the interaction function. While host rule of law has a negative coefficient in the communist host models, its relationship with offshore FDI is actually positive across the observed range of distances. This corroborates the finding of Haberly and Wójcik (2014) that the overall quantity of inward offshore FDI is not increased by weak host rule of law or communist history; the impact of these variables revealed here is rather qualitative. Likewise, the negative coefficient on $\log ($ distance $)$ does not indicate a universally inverse relationship between distance and offshore FDI. The negative coefficient on $\log ($ distance) in models 1.3-1.6, and 1.8 is approximately twice as large as the positive coefficient on (rule of law) $\mathrm{x} \log ($ distance $)$, corresponding to the maximum observed rule of law value of approximately two. This is a striking finding, indicating that sensitivity to distance drops almost exactly to zero for both communist and non-communist hosts with very strong rule of law.

This suggests an explanation for the finding of Haberly and Wójcik (2014) that offshore FDI is roughly as sensitive to distance as real FDI on average, notwithstanding its apparently fictitious nature, and the potential for OJs to be "remote controlled" from distant locations. It may also partially explain the heterogeneous juxtaposition of global centralization and regionalization within the offshore FDI network. Offshore FDI, it seems, may not have any generalized sensitivity to distance; rather, this might only emerge in interactions where formal legal contractual relationships are considered to be unreliable and or undesirable, and informal

${ }^{10}$ Counterintuitively, this worldwide effect is only detectable in a three-dimensional analysis that disaggregates hosts based on communist history, as evidenced by insignificance of rule of law $\mathrm{x} \log ($ distance) in models 1.1 and 1.2. This underscores the importance of the PCA finding of a qualitative discontinuity in offshore FDI patterns between these groups of countries in guiding model specification. 
relationships of trust — as mediated by face-to-face contact and physical travel—assume a compensatory role. The effect of communist history is best described as an amplification of this compensatory relationship for any given reduction in host rule of law. The reasons for this cannot be known with certainty, but may be related to the legacy of privatization and or disproportionate fear of property expropriation in former communist countries. Also difficult to determine, is whether increased reliance on trust and face-to-face contact necessarily indicates the use of secrecy to hide illegal behavior, or is compatible with law-abiding, institution-seeking interpretations of offshore activity. It is notable, however, that the impact of (bilateral) double taxation treaties is significantly positive for non-communist but not communist hosts, as treaties often undermine financial secrecy. This may point towards a predominance of "furtive capital" (Roberts 1994) in the Eastern Block network specifically.

The appropriate classification of China - the only former communist economy in the host sample not in Eastern Europe or Central Asia_-poses a dilemma, with sensitivity analysis indicating that its offshore FDI is unusual. Although model $r^{2} s$ suggest that its determinants are generally similar to Eastern Block economies, the China-distance interaction coefficient indicates exceptionally low sensitivity to distance, even in comparison to non-communist hosts. China is such an influential outlier that including it in the non-communist sample without the China-distance interaction term almost entirely confounds the detection of distance sensitivity (model 1.7). In conjunction with the network structures revealed by the PCA, these puzzling findings suggest a need for research examining the detailed interaction between insertion into regional business networks, and domestic post-socialist transition, in conditioning Chinese offshore activity. They also indicate a need for caution in using Chinese case studies to draw conclusions about developing and or transition economy offshore activity in general. 


\section{Conclusions: Conceptualizing the Offshore World}

The growing financialization of FDI underscores the need for analyses of the global economy which not only bridge the gap between financial and "real" activity, but also problematize the role of offshore legal constructs in defining the institutional geography of capital (Coe et al. 2014; Seabrooke and Wigan 2014). This paper has made a significant contribution to this agenda, by constructing the first map of the global offshore FDI network. Keeping in mind the limitations of the CDIS, ${ }^{11}$ the network organization revealed by the PCA results, analyzed in conjunction with regression tests of offshore FDI determinants, helps solidify our conceptualization of the evolutionary and organizational logic of the offshore world.

Information technology and the knowledge economy are indisputably intertwined with offshore finance, notably in the IP-mediated profit shifting embodied by a substantial portion of offshore FDI. As has often been demonstrated for onshore finance, however, our results cast doubt on the idea that the "hardware" of the offshore network itself is fundamentally technologydriven and footloose. Rather, the offshore world is best conceptualized as a legal-institutional infrastructure underpinning the global economy whose organization embodies the conservative, accretive process whereby laws, practices and relationships have emerged and been reproduced over long periods of time by communities of experts and elites. It has a hegemonic quality in this respect, reflecting not only the economic, political, and ideological predominance of the current superpower, but incorporating a succession of past preeminent capitalist empires and institutions, and evidencing a potential to absorb and adapt itself to future hegemonic regimes.

\footnotetext{
${ }^{11}$ Most importantly, the CDIS 1) is an incomplete sample of economies, producing geographic coverage gaps in Africa and the Middle East, and constraining our ability to probe the structure of "real" economy-to-OJ, as opposed to OJ-to-real economy FDI, 2) does not disaggregate FDI by investor nationality or activity, and 3) is new, meaning that results shed light on network development only when examined through the lens of other historical research.
} 
At a detailed level, the relational and institutional modalities of this infrastructure appear to be heterogeneous. PCA-guided regressions indicate that an economy's offshore ties are increasingly conditioned by trust and face-to-face contact as the strength of its legal institutions declines, and conversely by formal legal and public reputational factors, such as OECD membership, as institutional strength increases. This is an important finding, as it is the first systematic confirmation that the characteristics of offshore activity do in fact vary on the basis of national institutional strength. Superficially, at least, it might also be seen as evidence for a predominance of "furtive" versus "fictitious" activity in the developing and developed world respectively. However, this is far from conclusive, with only the former Soviet Bloc, where the relational substitution effect is much more prominent than elsewhere, showing corroborating evidence of a preference for secrecy. Moreover, our results indicate a need for caution in positing institutional causes for offshore activity, particularly either positive or negative institutional arbitrage by developing and transition economy firms. While it is possible that poor rule of law and communist history increase outgoing offshore FDI, we corroborate the finding of Haberly and Wójcik (2014) that they do not increase the quantity of incoming, including roundtrip, offshore FDI. Conceptually, institutional explanations for offshore activity risk conflating distinct questions, notably the means through which capital is accumulated, incentives for capital flight/round-tripping, incentives for capital intermediation through OJs, and factors conditioning which OJs are used. Our findings only directly relate to the last of these, and are compatible with a null hypothesis of universal incentives for OJ use (e.g. multifarious cost reduction), as suggested by Vlcek (2013). Indeed, the overall picture is of an offshore world in which demandside drivers are of secondary importance to the centralization of power at the supply side, as evidenced by a dominant "global finance" network with a largely homogenous global footprint. 
This power, it must be emphasized, is clearly not vested in offshore jurisdictions themselves, but rather in a broader "ABS-offshore nexus" (Wójcik 2013a). As Christensen and Hampton (1999) and Shaxson (2011) demonstrate, it is ABS firms which exercise the principal agency within offshore finance, and more often than not design the laws and regulations formally implemented by pliable OJ governments. With this in mind, the Global Financial Network (GFN) framework suggests a way forward in extending the work here, namely an examination of the relationships between legal abstractions established at the state-jurisdiction level (e.g. offshore FDI), and networks of ABS firms and professionals constituted at the urban scale of agglomerative processes. Our findings point towards tantalizing areas for emphasis, notably the relationship between the "Anglo-Alliance" and "Atlantic Axis" structures at the level of offshore FDI, and the so-called "NY-LON" (New York-London) dominant world city axis (Wójcik 2013b). On the other hand, the Global Wealth Chain perspective suggests a need for GFN to more directly situate offshore finance within the process of capital accumulation. In this respect, our findings suggest that longue durée world systems analyses of monopoly rent production have much to offer conceptually, with an engagement between approaches emphasizing the role of finance in mediating relationships between successive hegemons (Arrighi 1994), and those examining world city network formation (Taylor 2000), appearing particularly promising.

From a policy standpoint, the picture painted here casts doubt on the idea that the principal obstacle to offshore regulation is the corralling of numerous competing jurisdictions. While this amoebic character may prevail in peripheral portions of the offshore network, this has a centralized core likely to present a more stable target. However, core elements of this system are likely to be protected by the concentration of political and economic power represented by the "ABS-offshore nexus." The apparently deep historical roots of these structures have 
particularly important potential policy implications which increase the urgency of research on the evolution of offshore finance, including potential pre- $20^{\text {th }}$ century analogs. To the extent that offshore finance, in some form, is a deeply rooted product of the interaction of global capitalism with the sovereign state system, this would cast doubt on attempts to regulate offshore activity specifically, which have assumed that it can be decoupled from globalization generally. In the confident assessment of one offshore professional, "There will always be an offshore sector. We are the ball bearings in the machine of the world's financial markets" (quoted in Rawlings 2005).

\section{References}

Aoyama, Y., Benner, C., Berndt, C., Coe, N. M., Engelen, E., Essletzbichler, J., Glassman, J., Glueckner, J., Grote, M., Jones, A., Leichenko, R., Leslie, D., Lindner, P., Lorenzen, M., Mansfield, B., Murphy, J.T., Pollard, J.S., Power, D., Stam, E., Wójcik, D. and Zook, M. 2011. Emerging themes in economic geography: Outcomes of the Economic Geography 2010 workshop. Economic Geography, 87: 111-126.

Arrighi, G. 1994. The long twentieth century: Money, power, and the origins of our times. London: Verso.

Baker, R. W. 2005. Capitalism's Achilles heel: Dirty money and how to renew the free-market system. London: John Wiley and Sons.

Barford, V., Holt, G. 2013. The rise of 'tax shaming.' BBC News, May 21. Available online: http://www.bbc.co.uk/news/magazine-20560359

Baud, C. and Durand, C. 2012. Financialization, globalization and the making of profits by leading retailers. Socio-Economic Review, 10: 241-266.

Blonigen, B. A. and Davies, R. B. 2004. The effects of bilateral tax treaties on U.S. FDI activity. International Tax and Public Finance, 11: 601-622.

Brovkin, V. 2001. Moving money, making money, and parking money overseas: Front companies in offshore jurisdictions. Demokratizatsiya, 9.

Bureau of Economic Analysis (BEA). 2013. US direct investment abroad on a historical cost basis, 2012. Available online: http://www.bea.gov/international/dilusdbal.htm

Beaverstock, J. V., Smith, R. G., Taylor, P. J. 2000. World city network: A new metageography? Annals of the Association of American Geographers, 90: 123-134. 
Christensen, J., and Hampton, M. P. 1999. A legislature for hire: The capture of the state in Jersey's offshore finance centre. In Offshore finance centers and tax havens: The rise of global capital, ed. M. P. Hampton and J. P. Abbott, 166-199. West Lafayette: Purdue University Press.

Clark, G. L., and O'Connor, K. 1997. The informational content of financial products and the spatial structure of the global finance industry. In Spaces of globalization: Reasserting the power of the local, ed. K. R. Cox, 89-114. New York: Guilford Press.

Coates, N., and Rafferty, M. 2007. Offshore financial centres, hot money and hedge funds: A network analysis of international capital flows. In Global finance in the new century: Beyond deregulation, ed. L. Assassi, A. Nesvetailova and D. Wigan, 38-54. Houndmills: Palgrave Macmillan

Cobb, S. C. 1998. Global finance and the growth of offshore financial centers: the Manx experience. Geoforum, 29: 7-21.

Coe, N. M., Lai, K. P. Y., Wójcik, D. 2014. Integrating finance into global production networks. Regional Studies, 48: 761-777.

Desai, M. A., Foley, C. F., Hines, J. R. 2004. Economic effects of regional tax havens. NBER working paper 10806. Available online:

http://www.nber.org/papers/w10806.pdf?new_window=1

Dharmapala, D. 2008. What problems and opportunities are created by tax havens? Oxford Review of Economic Policy, 24: 661-679.

Dicken, P. J. 2011. Global shift: Mapping the changing contours of the world economy (6 ${ }^{\text {th }}$ ed.). London: SAGE.

Ding, X. L. 2000. Informal privatization through internationalization: The rise of Nomenklatura capitalism in China's offshore businesses. British Journal of Political Science, 30: 121-146.

Dixon, A. D. 2011. Variegated capitalism and the geography of finance: towards a common agenda. Progress in Human Geography, 35: 193-201.

Eden, L. and Kudrle, R. T. 2005. Tax havens: Renegade states in the international tax regime? Law \& Policy, 27: 100-127.

Findley, M., Nielson, D., Sharman, J. 2012. Global shell games: Testing money launderers' and terrorists' access to shell companies. Political Economy and Development Lab research report. Available online: http://scholar.byu.edu/sites/default/files/danielnielson/files/pedl_report.pdf

Froud, J. Haslam, C., Johal, S., Williams, K. 2000. Shareholder value and financialization: Consultancy promises, management moves. Economy and Society, 29: 80-110. 
Guillen, M. F., and Tschoegel, A. E. 2000. The internationalization of retail banking: The case of the Spanish banks in Latin America. Transnational Corporations, 9: 63-98.

Greguras, F. M., Bassett, B., Zhang, J. 2008. 2008 update to doing business in China via the Cayman Islands. Fenwick \& West LLP Memorandum. Available online: http://www.fenwick.com/FenwickDocuments/2008_Update_Business_China.pdf

Haberly, D. 2013. White knights from the gulf: Sovereign wealth fund investment and the evolution of German industrial finance. Economic Geography, DOI: 10.1111/ecge.12047.

Haberly, D., Wójcik, D. 2013. Tax havens and the production of offshore FDI: An empirical analysis. University of Oxford, School of Geography and the Environment working papers in employment, work and finance 13-02. Available online:

http://papers.ssrn.com/sol3/papers.cfm?abstract_id=2252431

Hayton, J. C., Allen, D. G., Scarpello, V. 2004. Factor retention decisions in exploratory factor analysis: A tutorial on parallel analysis. Organizational Research Methods, 7: 191-205.

Henry, J. S. 2012b. Revised estimates of private banking assets under management and total client assets - top-50 global private banks, 2005-2010. Tax Justice Network research report. Available online: http://taxjustice.blogspot.ch/2012/07/the-price-of-offshore-revisited-and.html

Hong, Q., Smart, M. 2010. In praise of tax havens: International tax planning and foreign direct investment. European economic review, 54: 82-95.

LaFranco, R., Sazanov, A. 2013. How Russia's 20 biggest billionaires hide their fortunes from the government. Bloomberg News, May 1. Available online:

http://business.financialpost.com/2013/05/01/how-russias-20-biggest-billionaires-hide-theirfortunes-from-the-government/

Lazonick, W., Tulum, Oner. 2011. US biopharmaceutical finance and the sustainability of the biotech business model. Research Policy Journal, 40: 1170-1187.

Ledyaeva, S., Karhunen, P., Whalley, J. 2013. If foreign investment is not foreign: Round-trip vs. genuine foreign investment in Russia. Working paper. Available online: https://tippie.uiowa.edu/economics/tow/papers/ledyaeva-spring2013.pdf

Lee, R., Clark, G. L., Pollard, J., Leyshon, A. 2009. The remit of financial geography-before and after the crisis. Journal of Economic Geography, 9: 723-747.

Lewellen, K., Robinson, L. 2013. Internal ownership structures of U.S. multinational firms. Working paper. Available online: http://faculty.tuck.dartmouth.edu/images/uploads/faculty/leslie-robinson/LewellenRobinson.pdf

Leyshon, A., and Thrift, N. 1997. Money/space: Geographies of monetary transformation. London: Routledge. 
MacCallum, R. C., Widaman, K. F., Zhang, S. and Hong, S. 1999. Sample size in factor Analysis. Psychological Methods, 4: 84-99.

Milberg, W. 2008. Shifting sources and uses of profits: Sustaining US financialization with global value chains. Economy and Society, 37: 420-451.

Oxfam. 2000. Tax havens: Releasing the hidden billions for development. Oxfam GB Policy Paper.

Palan, R., Murphy, R., and Chavgneux, C. 2010. Tax havens: How globalization really works. Ithaca: Cornell University Press.

Palpacuer, F. 2008. Bringing the social context back in: Governance and wealth distribution in global commodity chains. Economy and Society, 37: 393-419.

Peck, J., and Theodore N. 2007. Variegated capitalism. Progress in Human Geography, 31: 731772

Picciotto, S. 1999. Offshore: the state as legal fiction. In Offshore Finance Centers and Tax Havens: the Rise of Global Capital, ed. M. P. Hampton and J. P. Abbott, 43-79. West Lafayette: Purdue University Press.

Rawlings, G. 2005. Mobile people, mobile capital and tax neutrality: Sustaining a market for Offshore Finance Centres. Accounting Forum, 29: 289-310.

Rawlings, G. 2007. Taxes and transnational treaties: Responsive regulation and the reassertion of offshore sovereignty. Law \& Policy, 29: 51-66.

Roberts, S. 1994. Fictitious capital, fictitious spaces: The geography of offshore financial flows. In Money, power and space, ed. R. Martin, N. Thrift, S. Corbridge, 91-115. Oxford: Blackwell.

Seabrooke, L., and Wigan, D. 2014. Global wealth chains in the international political economy. Review of International Political Economy, 21: 257-263.

Sharman, J. C. 2005. South Pacific tax havens: From leaders in the race to the bottom to laggards in the race to the top? Accounting Forum, 29: 311-323.

Sharman, J. C. 2012. Chinese capital flows and offshore financial centers. The Pacific Review, 25: $317-337$.

Shaxson, N. 2011. Treasure islands: Tax havens and the men who stole the world. London: Vintage.

Sikka, P. Willmott, H. 2010. The dark side of transfer pricing: Its role in tax avoidance and wealth retentiveness. Critical Perspectives on Accounting, 21: 342-356. 
Spillane, C. 2012. Chinese, Southeast Asians purchase half of new London homes. Bloomberg News, April 20. Available online: http://www.bloomberg.com/news/2012-04-19/chinesesoutheast-asians-buy-half-of-new-central-london-homes.html

Stal, E., Cuervo-Cazurra, A. 2011. The investment development path and FDI from developing countries: The role of pro-market reforms and institutional voids. Latin American Business Review, 12: 209-231.

Sutherland, D., El-Gohari, A., Buckley, P. J., Voss, H. 2010. The role of Caribbean tax havens and offshore financial centres in Chinese outward foreign direct investment. Working paper. Available online: http://gdex.dk/ofdi10/Dylan\%20Sutherland\%20\%20-\%20et\%20al.pdf

Tax Justice Network (TJN). 2012. 2011 financial secrecy index. Available online: http://www.financialsecrecyindex.com/2011results.html

Taylor, P. J. 2000. World cities and territorial states under conditions of contemporary globalization. Political Geography, 19: 5-32.

Taylor, P. J., Catalana, G. and Walker, D. (2004) Multiple globalisations: Regional, hierarchical and sectoral articulations of global business services through world cities. Service Industries Journal, 24: 63-81.

Thrift, N. 1994. On the social and cultural determinants of international financial centres: The case of the City of London. In Money, power and space, ed. R. Martin, N. Thrift, S. Corbridge, 327-255. Oxford: Blackwell.

Ting, A. 2014. iTax-Apple's international tax structure and the double non-taxation issue. British Tax Review, 1: 40-71.

Vlcek, W. 2007. Why worry? The impact of the OECD Harmful Tax Competition Initiative on Caribbean offshore financial centres. The Round Table, 96: 331-346.

Vlcek, W. 2013. From Road Town to Shanghai: Situating the Caribbean in global capital flows to China. The British Journal of Politics \& International Relations, 15.

Vyas, S., Kumaranayake, L. 2006. Constructing socio-economic status indices: How to use principal component analysis. Health Policy Plan, 21: 459-468.

Walter, C. E., Howie, F. J. T. 2010. Red capitalism: The fragile financial foundations of China's extraordinary rise. Singapore: John Wiley \& Sons.

Warf, B. 2002. Tailored for Panama: Offshore banking at the crossroads of the Americas. Geografiska Annaler, 84: 33-47. 
Weichenrieder, A. J. and Mintz, J. 2008. What determines the use of holding companies and ownership chains? Oxford University Centre for Business Taxation working paper Series 803. Available online:

http://www.sbs.ox.ac.uk/centres/tax/symposia/Documents/2007/A\%20Weichenrieder\%20Holdin g_companies_15March07.pdf

Weidenbaum, M. L., Hughes, S. 1996. The bamboo network: How expatriate Chinese entrepreneurs are creating a new economic superpower in Asia. New York: Simon \& Schuster.

Weyzig, F. 2012. Tax treaty shopping: Structural determinants of foreign direct investment routed through the Netherlands. International Tax and Public Finance, September.

Wójcik, D. 2013a. Where governance fails: Advanced business services and the offshore world. Progress in Human Geography, 37: 330-347.

Wójcik, D., 2013b, The dark side of NY-LON: Financial centres and the global financial crisis. Urban Studies, 50, 13: 2736-52.

World Bank. 2012. World governance indicators. Available online:

http://info.worldbank.org/governance/wgi/index.asp.

Yeung, H. W. C. 1999. The internationalization of ethnic Chinese business firms from Southeast Asia: Strategies, processes, and competitive advantage. International Journal of Urban and Regional Research, 23: 88-102.

Zorome, A. 2007. Concept of offshore financial centers: In search of an operational definition. IMF working paper 07/08.

Appendix 1. Tax Haven status of leading OFDI/GDP jurisdictions

\begin{tabular}{|c|c|c|c|c|c|c|c|}
\hline Jurisdiction & $\begin{array}{c}\% \\
\text { World } \\
\text { OFDI }\end{array}$ & $\frac{\text { OFDI }}{\text { GDP }}$ & $\begin{array}{l}\text { Tax } \\
\text { Haven } \\
\text { Score }\end{array}$ & Jurisdiction & $\begin{array}{c}\% \\
\text { World } \\
\text { OFDI }\end{array}$ & $\frac{\text { OFDI }}{\text { GDP }}$ & $\begin{array}{l}\text { Tax } \\
\text { Haven } \\
\text { Score }\end{array}$ \\
\hline $\begin{array}{l}\text { British Virgin Islands } \\
\text { Cayman Islands }\end{array}$ & $\begin{array}{l}3.2 \\
1.1\end{array}$ & $\begin{array}{l}632.67 \\
103.66\end{array}$ & $\begin{array}{l}10 \\
11\end{array}$ & $\begin{array}{l}\text { Switzerland } \\
\text { Ireland }\end{array}$ & $\begin{array}{l}3.7 \\
1.2\end{array}$ & $\begin{array}{l}1.51 \\
1.21\end{array}$ & $\begin{array}{l}9 \\
8\end{array}$ \\
\hline Bermuda & 2.1 & 78.38 & 11 & Singapore & 1.2 & 1.17 & 9 \\
\hline Cook Islands & 0.04 & 45.57 & 8 & United Kingdom & 11 & 1.07 & 3 \\
\hline Samoa & 0.08 & 34.51 & 6 & Belize & 0.01 & 1.05 & 8 \\
\hline Luxembourg & 7.7 & 30.30 & 8 & Anguilla & 0.00 & 1.04 & 7 \\
\hline Neth. Antilles & 0.31 & 16.44 & 10 & Belgium (OECD) & 2.1 & 0.95 & 1 \\
\hline Marshall Islands & 0.01 & 15.65 & 7 & St V. \& the Gren. & 0.00 & 0.93 & 9 \\
\hline Am. Samoa & 0.03 & 14.50 & 2 & St. Kitts and Nev. & 0.00 & 0.87 & 8 \\
\hline $\begin{array}{l}\text { Cyprus } \\
\text { la }\end{array}$ & 1.2 & 11.36 & 10 & $\begin{array}{l}\text { Panama } \\
\text { Pame }\end{array}$ & 0.10 & 0.81 & 11 \\
\hline Guernsey & 0.14 & 11.19 & 11 & Sweden & 1.5 & 0.71 & 0 \\
\hline Gibraltar & 0.06 & 11.10 & 9 & Austria & 1.2 & 0.70 & 0 \\
\hline Mauritius & 0.46 & 10.23 & 7 & Iceland & 0.04 & 0.69 & 1 \\
\hline Niue & 0.00 & 10.23 & 5 & Dominica & 0.00 & 0.68 & 6 \\
\hline Liberia & 0.05 & 9.86 & $\overline{6}$ & Hungary & 0.39 & 0.64 & 2 \\
\hline Jersey & 0.22 & 9.27 & 11 & Finland & 0.61 & 0.55 & 0 \\
\hline Bahamas & 0.23 & 6.56 & 11 & San Marino & 0.00 & 0.48 & 1 \\
\hline Seychelles & 0.03 & 6.35 & 6 & France & 5.0 & 0.42 & 1 \\
\hline Barbados & 0.11 & 5.53 & 10 & Denmark & 0.60 & 0.42 & 0 \\
\hline Hong Kong & 3.8 & 3.62 & 9 & St. Lucia & 0.00 & 0.33 & 6 \\
\hline Isle of Man & 0.04 & 3.34 & 10 & Uruguay & 0.06 & 0.32 & 2 \\
\hline Nauru & 0.00 & 2.97 & 8 & Canada & 2.3 & 0.31 & 0 \\
\hline Netherlands & 10 & 2.77 & 2 & Germany & 4.7 & 0.31 & 1 \\
\hline Malta & 0.08 & 2.08 & 11 & Macao & 0.05 & 0.30 & 4 \\
\hline Liechtenstein & 0.04 & 1.89 & 10 & Andorra & 0.01 & 0.29 & 7 \\
\hline
\end{tabular}

Sources: IMF (FDI, GDP data); Palan et al. 2010 (Tax Haven Score). 